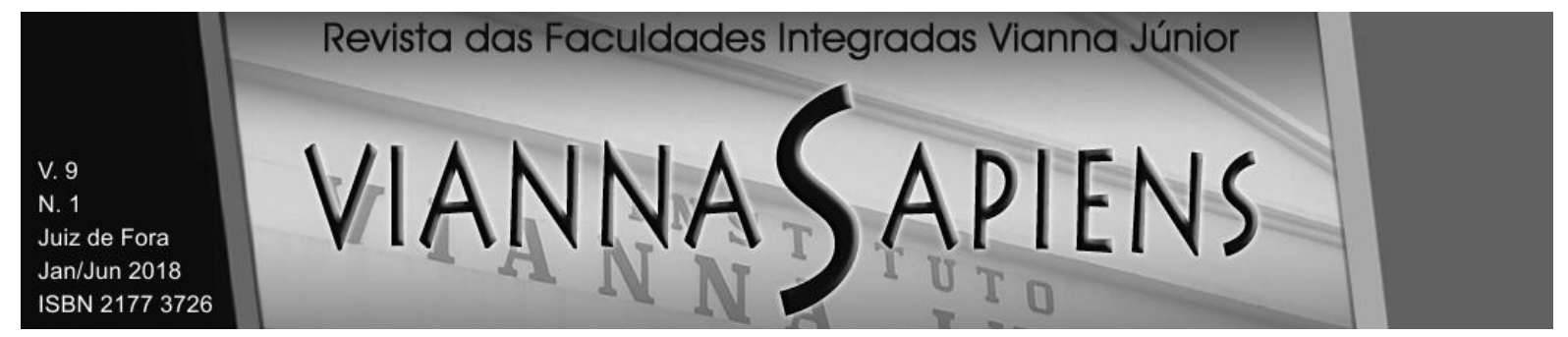

\title{
A POSSIBILIDADE DO PEDIDO DE DIVÓRCIO INAUDITA ALTERA PARTE:
}

\section{Os Princípios Processuais versus a Autonomia da Vontade}

DOI: 10.31994/rvs.v9i1.337

Laís Malinconico Felipe ${ }^{1}$

Loren Dutra Franco ${ }^{2}$

\begin{abstract}
RESUMO
Este estudo objetiva demonstrar a possibilidade da concessão do divórcio em caráter liminar, inaudita altera parte, tanto em relação a uma análise doutrinária e dogmática quanto à análise dos casos citados, especialmente os primeiros ocorridos no Brasil e na cidade de Juiz de Fora, Minas Gerais. Assim, pretendese demonstrar, a princípio, que apesar da nova possibilidade judicial resultante das diversas necessidades da sociedade e da vida conjugal que está por terminar, há de ser observar os limites pelos quais se fundam o pedido e os princípios processuais da ampla defesa e do contraditório, oriundos do devido processo legal, que não deve ser violado. Para tanto, a natureza da pesquisa foi baseada no método descritivo-interpretativo, utilizando-se julgados, jurisprudências, doutrinas, documentos e análises de processos judiciais a fim de se obter um resultado qualitativo neste trabalho. Deste modo, conclui-se que caberá aos juízes e intérpretes do direito, perante a análise do caso concreto,
\end{abstract}

\footnotetext{
${ }^{1}$ Advogada, Bacharel em Direito pelas Faculdades Integradas Vianna Júnior, Juiz de Fora-MG ; Instituição Faculdades Integradas Vianna Jr., laismalinconico@gmail.com.ORCID:000-0003-05615242

${ }_{2}^{2}$ Mestre em Direito e Políticas Públicas pelo UniCeub, Brasília- DF, pós-graduada em Direito Processual Civil pela Unifenas - MG, graduada em Direito pelas Faculdades Integradas Vianna Jr., professora de Direito Civil parte geral, obrigações e contratos pelas Faculdades Integradas Vianna Jr. Juiz de Fora-MG e pesquisadora do grupo de pesquisa Direito e Desenvolvimento sustentável do UniCEUB- Brasília- DF. Instituição Faculdades Integradas Vianna Jr. lorendfranco@gmail.com . ORCID:000-0002-1268-6770.
} 


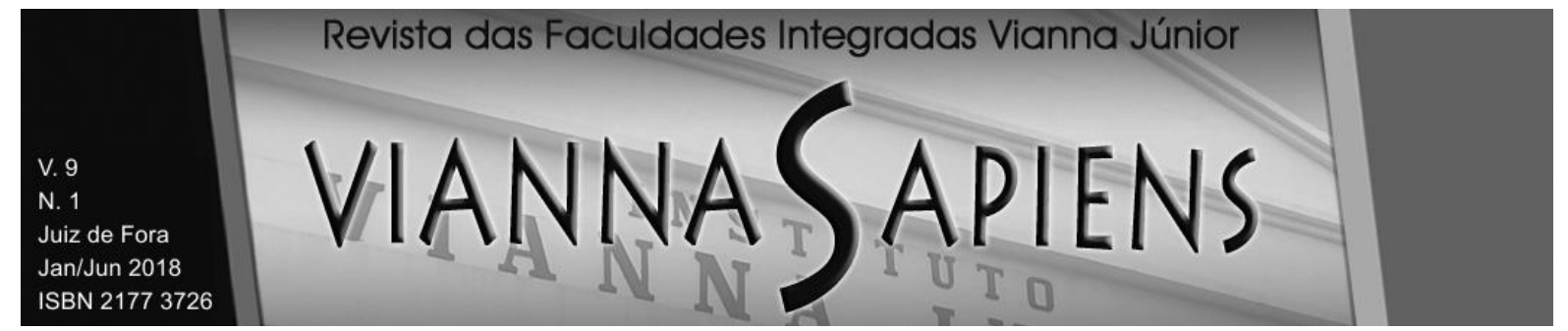

entender as circunstâncias que ensejam o pedido e o cabimento do mesmo, visando facilitar o procedimento do divórcio pela vontade das partes em adiantar a felicidade que tanto se busca com o pedido judicial.

\section{PALAVRAS-CHAVE: DIVÓRCIO. ANTECIPAÇÃO DE TUTELA. INAUDITA ALTERA PARTE. FELICIDADE. AUTONOMIA DA VONTADE.}

\section{INTRODUÇÃO}

A possibilidade do divórcio mudou as concepções de família através dos tempos e permitiu-se adequar às necessidades daqueles que, enxergando um novo futuro, faziam imprescindível a sua atuação. Levando em consideração o casamento como um contrato e o divórcio como um distrato, é importante destacar a autonomia da vontade quando falamos no desejo de não estar mais com o cônjuge em vida matrimonial. A grande questão é se a decretação do divórcio, em caráter liminar, inaudita altera parte, ao evitar um desnecessário prolongamento da demanda, fere os princípios da ampla defesa e do contraditório. Contudo, para que haja essa reflexão, é necessária a análise principiológica, a fim de ponderar os limites da autonomia da vontade dos cônjuges litigantes ao traçarem a busca pela felicidade afetiva.

Diante dessas reflexões, o objetivo deste trabalho foi debater a possibilidade da decretação do divórcio em caráter liminar, inaudita altera parte, uma vez demonstrado os princípios basilares do contraditório e da ampla defesa, de modo a discutir se a vontade das partes é requisito único e indispensável para a decretação do divórcio, e ainda, se este tipo de provimento judicial viola o contraditório constitucionalmente previsto como princípio, levando em consideração a autonomia das partes em não permanecer mais em vínculo matrimonial e exercendo o direito implícito pela busca da felicidade.

Para corroborar essa discussão, foram analisados julgados, assim como 


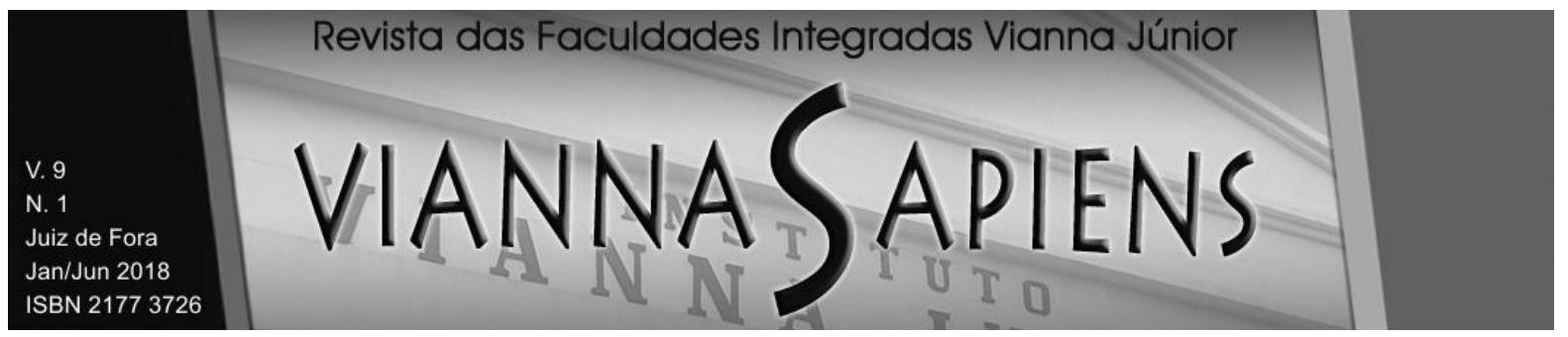

doutrinas, jurisprudências, pesquisas bibliográficas e processos judiciais de casos semelhantes, a fim de se extrair um resultado qualitativo, consubstanciado no método descritivo-interpretativo, com o intuito de respaldar a tese jurídica discutida.

Consequentemente, para abordar tais questões, o presente trabalho foi dividido em itens, sendo que inicialmente serão apurados os princípios norteadores do contraditório e da ampla defesa, com o intuito de corroborar a discussão. Assim, logo adiante, ponto chave deste estudo, abordará especificamente os casos em que ocorreram a decretação do divórcio inaudita altera parte, analisando como ficam os critérios da ponderação entre a felicidade das partes, a autonomia da vontade e os princípios processuais, resultando, ao final, as conclusões obtidas.

\section{DOS PRINCÍPIOS PROCESSUAIS: a ampla defesa e o contraditório}

Os princípios processuais constituem a formação do próprio processo, sendo imprescindíveis à função jurisdicional. Essas são as palavras de Cássio Scarpinella Bueno (2016, p. 43) acerca dos princípios processuais propriamente ditos: "os princípios são essenciais para a compreensão desse mínimo essencial do direito processual civil." Ainda nos ensinamentos do jurista, são os princípios processuais que concedem as diretrizes mínimas para a formação e desenvolvimento do próprio processo.

De acordo com o que foi citado acima por Bueno (2016, p. 44), não se pode falar em divórcio sem se referir ao seu procedimento. Muito mais do que um conceito de direito material, o divórcio se consubstancia e integraliza mediante processo. Uma das peculiaridades deste estudo é a observância dos princípios da ampla defesa e do contraditório, no processo de divórcio.

\subsection{Da ampla defesa}

Prevê o artigo $5^{\circ}$ da CF/88, inciso LV: 


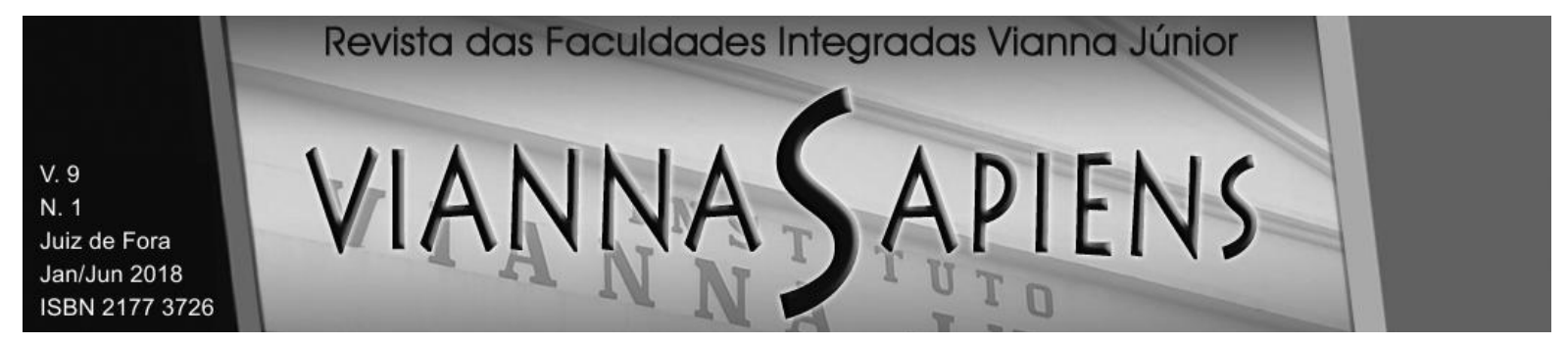

LV - aos litigantes, em processo judicial ou administrativo, e aos acusados em geral são assegurados o contraditório e ampla defesa, com os meios e recursos a ela inerentes;

Partindo direto ao conceito (BUENO, 2016) a ampla defesa, princípio processual constitucionalmente positivado, apregoa que aquele intitulado como réu em processo judicial, seja ele civil, administrativo ou criminal, terá as efetivas e concretas garantias de responder ao que lhe é imputado, antes mesmo dessas imputações surtirem efeitos. Nos ditames de Cássio Scarpinella Bueno (2016, p. 48):

Não são recursos em sentido técnico, em sentido processual, como mecanismos de revisão ou de controle de decisões judiciais. A própria concepção de um "direito fundamental à prova" pode e deve ser entendida como uma forma de bem realizar o comando constitucional aqui destacado, isto é, como meio de se exercer amplamente a defesa.

Trazendo ao assunto em tela, em uma Ação de Divórcio, impossível deixar de observar a ampla defesa diante da manifestação da vontade de um dos cônjuges. Inerente ao devido processo legal, a ampla defesa constrói, juntamente com os demais princípios processuais o que - tão maravilhosamente - é o que se chama de Estado Democrático de Direito.

Como pode ser iniciado um processo judicial, ainda mais uma ação de divórcio, sem que haja a ampla defesa? Da mesma forma em que há a palavra como mecanismo do pensamento, concretizada em atitude, no momento do casamento, haverá de ter também no momento de descasar. A inobservância da ampla defesa, neste caso, ocasiona cerceamento de defesa infundado, além de possibilitar a complicação da relação afetiva entre os cônjuges, em separação, e toda a sociedade familiar envolvida, atingindo os filhos, se houver, e trazendo consequências gravíssimas ao seio familiar. 


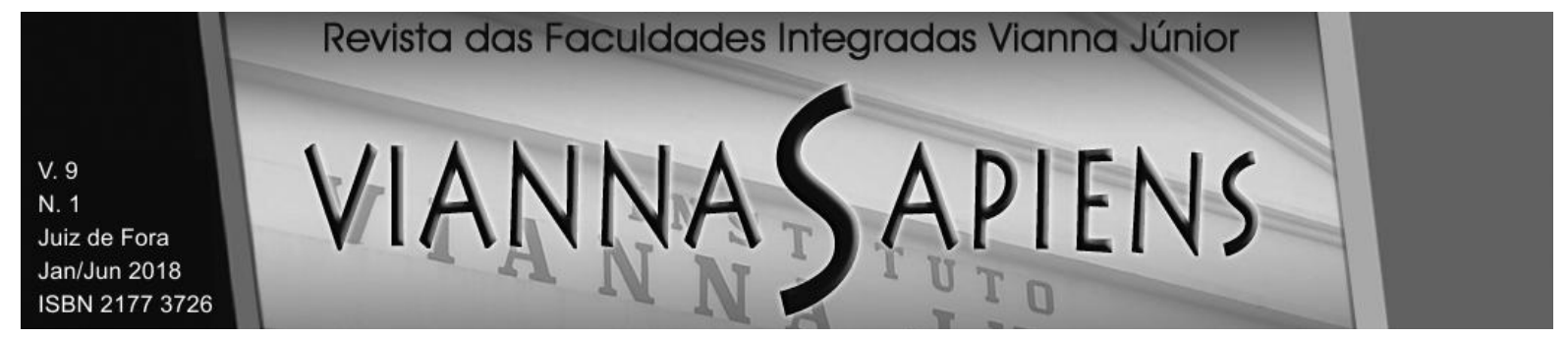

\subsection{Do Contraditório}

Também previsto no mesmo artigo $5^{\circ}$, inciso $\mathrm{LV}$, da $\mathrm{CF} / 88$, este princípio é conhecido por parte da doutrina como princípio da audiência bilateral. Para entender o significado e suas consequências no mundo jurídico, o contraditório é o princípio pelo qual o juiz não deverá decidir sem ouvir ambas as partes. "Dar ao réu, no processo, oportunidade de se defender, é premissa fundamental do Estado de Direito, previstas em todas as Constituições Democráticas" (ACQUAVIVA, 2013).

Nos ensinamento de Cássio Scarpinella Bueno (2016, p. 46), o núcleo identificador do princípio do contraditório, a fim de diferenciá-lo da ampla defesa, é o binômio 'informação-reação'. Para que haja a premissa do contraditório é necessário contradizer alguma coisa. Daí nasce a reação a partir da informação dada ao réu, da ação, de que algo é alegado em desfavor dele.

Entendido que o contraditório é meio essencial à prestação da tutela jurisdicional, pergunta-se se haveria a possibilidade de se conceder o divórcio a um casal que deseja se separar ouvindo somente um deles. Ora, se no momento do sim, ambos devem concordar, porque no momento do não haveria de ser diferente? Espantoso seria saber que alguém teve, sem ser ouvido, o divórcio de sua relação matrimonial decretada. Mas afinal, haveria essa possibilidade?

\section{DOS PRINCÍPIOS DA AMPLA DEFESA E DO CONTRADITÓRIO QUANDO DA CONCESSÃO DO DIVÓRCIO EM CARÁTER LIMINAR: ANÁLISE DO CASO CONCRETO}

Trata-se da análise do caso concreto ocorrido na Comarca de Juiz de Fora MG, onde, pela primeira vez na região, em pedido inaugural, Marcelo Santos Mazocoli, advogado militante da área de direito de família, requereu a decretação do divórcio de sua cliente, em caráter liminar, inaudita altera parte. 


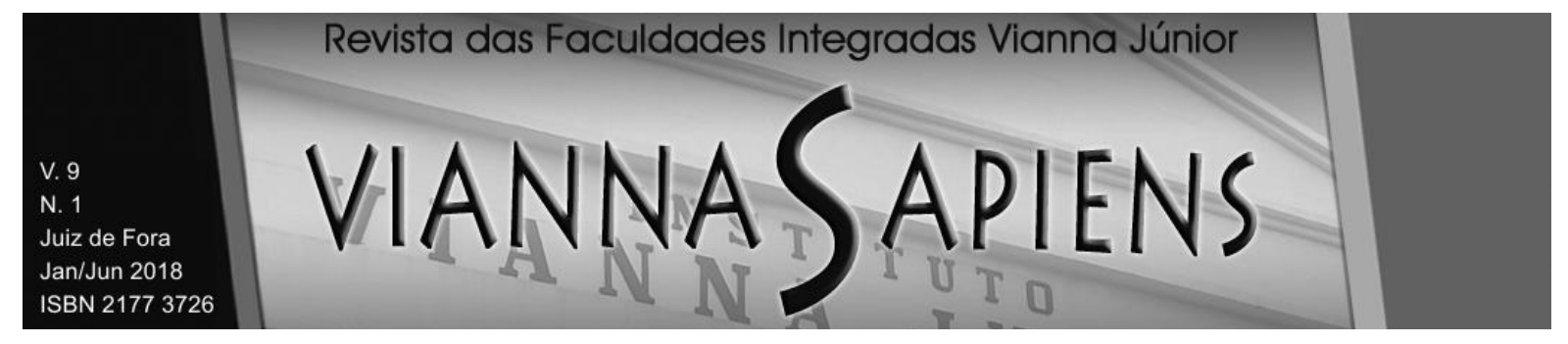

Em síntese, este é o caso: o marido, casado com sua esposa e com três filhos, abandona o lar conjugal e parte para local incerto e não sabido. Só, a esposa constitui nova união estável. Após 42 anos de desaparecimento do marido e desejando ver concretizada a nova relação amorosa, ela constitui advogado para requerer o que lhe é de direito. Ocorre que, o doravante denominado réu, não fora encontrado para responder aos limites da lide. Desta forma, em sede de Inicial, posteriormente reiterado em Agravo de Instrumento, foi pleiteado a decretação do divórcio liminar inaudita altera parte.

Em análises anteriormente feitas, chega-se a conclusão de que a vontade das partes é requisito - único e fundamental - para a decretação do divórcio. Neste caso, não haveria a possibilidade do outro cônjuge manifestar seu desejo, visto que em local incerto e não sabido. Assim, questiona-se o poder e a eficácia do contraditório quando não surtir efeito convincente à decisão judicial. Nesta toada, é o posicionamento de Marcelo Santos Mazocoli (Ag n 1014511029255-7/001, 2012):

Logo, se o direito ao divórcio se tornou incontroverso e se a parte ré não pode influenciar no convencimento do juiz a fim de tentar impedir o deferimento do pedido (contraditório material ou substancial), perfeitamente aplicável é a antecipação de tutela o prevista no CPC, ainda que inaudita altera parte.

E reitera este posicionamento Nelson Nery Júnior (2003, p. 307):

Quando a citação do réu puder tornar ineficaz a medida, ou, também, quando a urgência indicar a necessidade de concessão imediata da tutela, o juiz poderá fazê-lo inaudita altera parte, o que não constitui ofensa, mas sim limitação imanente do contraditório, que fica diferido para momento posterior do procedimento.

Diz-se liminar aquela decisão pretendida - e concedida - limini litis, quer dizer, no início da lide, momento processual de abertura do processo, nascedouro do litígio (BUENO, 2016). Quando se trata da matéria de antecipação dos efeitos da tutela jurisdicional, sem adentrar na discussão quanto à sua natureza e espécies, 


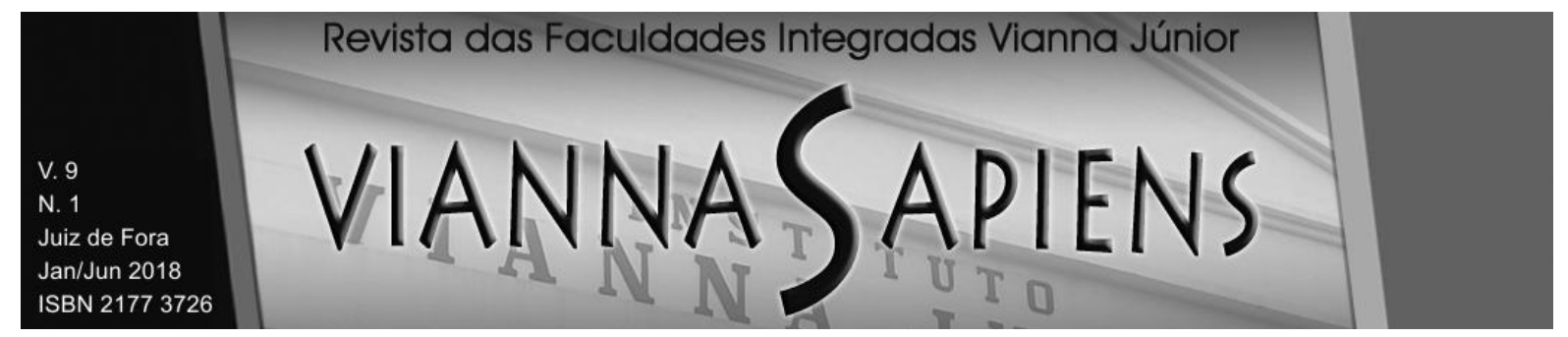

nota-se a possibilidade da concessão da mesma em caráter inaudita altera parte. Advinda da expressão em latim inaudita altera pars, inaudita altera parte quer dizer 'sem ouvir a outra parte', sem que seja escutada a parte contrária.

Com os elementares conceitos definidos, é o grande questionamento: pode um divórcio ser concedido liminarmente, antecipando-se os efeitos jurisdicionais da tutela pretendida, ainda que não ouvida a parte contrária? Nas palavras de Cássio Scarpinella Bueno (2016, p. 255), "a concessão liminar de um pedido é absolutamente harmônico com o "modelo constitucional". É situação bem aceita de preponderância do princípio da efetividade do direito material pelo processo sobre os princípios do contraditório e da ampla defesa".

Para que a decisão seja em caráter liminar, possivelmente esta será inaudita altera parte, já que este tipo de requerimento é feito em momentos de urgência, mediante comprovação do fumus boni iuris e periculum in mora. Havendo a audição da parte contrária, não se falaria em pedido liminar. No presente caso, a autora da ação tinha urgência em ver sua união estável convertida em casamento. Mas, para que isso ocorresse, tinha que se desatar os nós da primeira união.

Pois bem, e como ficariam os princípios da ampla defesa e do contraditório mediante o requerimento judicial deste pedido? Já foi analisado que, para a concessão do divórcio, pós Emenda Constitucional n 66/2010, o único requisito é a declaração de vontade das partes. Acredita-se que a grande questão é analisar e superar o fato de que o contraditório não deixará de ser observado, somente será postergado.

Nos ensinamentos de Cássio Scarpinella Bueno (2016, p. 255), muito bem explanado é que a hipótese envolve mera postergação do contraditório, e não sua eliminação, sendo a mesma legítima para que se ouça o réu em casos de urgência, ainda que designada, futuramente, audiência. Neste sentido foi a decisão do Tribunal de Justiça do Estado do Mato Grosso, em 2012:

Ação de divórcio litigioso c/c partilha de bens - decreto do divórcio em sede de liminar - alteração do art. 226, § 6 da CF com a redação dada pela emenda constitucional $66 / 2010$ - supressão do requisito da 


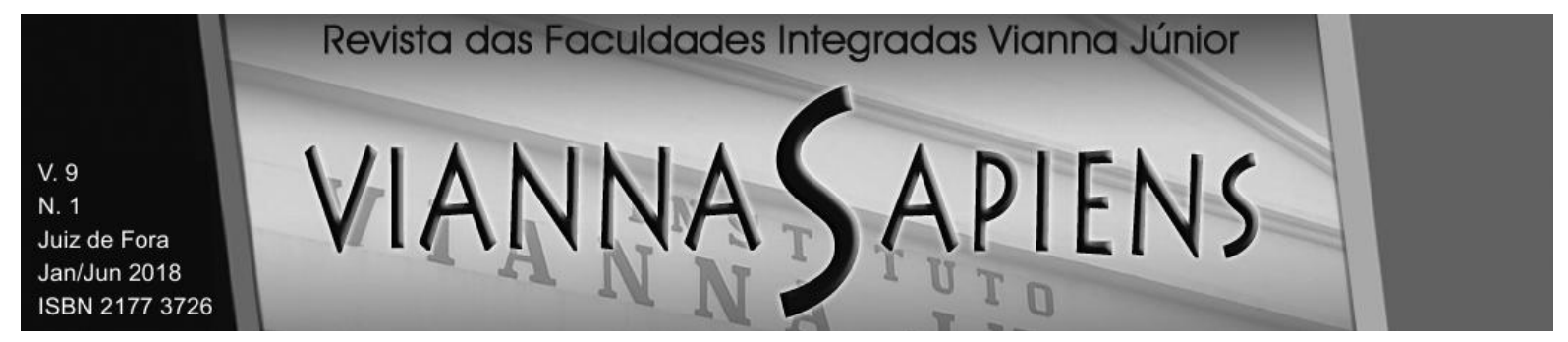

prévia separação - desnecessidade de aguardar a audiência de tentativa de conciliação - recurso desprovido. O legislador constitucional, ao editar a emenda constitucional 66/2010, retirou o requisito da separação daqueles que pretendem extinguir a relação matrimonial. Logo, é plenamente possível a demandante pleitear o divórcio liminarmente, não se podendo indagar a respeito da culpa stricto sensu, pois independe de qualquer condição ou fato e também da vontade do outro cônjuge.

(Agravo de instrumento no 99447/2011, 2ª câmara cível do TJMT, rel. clarice claudino da silva. j. 25.01.2012, unânime, dje 09.02.2012).

Afirma ainda Mazocoli, em sede de Agravo de Instrumento de

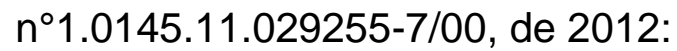

Lado outro, com o advento da emenda constitucional de n. 66, o divórcio se tornou direito potestativo da parte interessada, bastando que esteja casada para a sua obtenção, não podendo, sequer, submetê-lo à controvérsia, sob pena de gritante afronta ao texto constitucional que propiciou a facilitação da dissolução nupcial.

Quando a separação deixou de ser contemplada pela Constituição Federal em 2010, com a PEC do Divórcio - chamada de PEC do Amor para Pablo Stolze Gagliano e Rodolfo Pamplona (2016, p. 45) - o Estado buscou afastar-se da intimidade das relações conjugais, reconhecendo suas autonomias para extinguir, por sua livre vontade, o vínculo matrimonial, sem a necessidade do lapso temporal. (GAGLIANO e PAMPLONA FILHO, 2016). Isso é que se configura o simples exercício de um direito potestativo. Logo, não restam dúvidas de que o réu não possuiria meios de influenciar a decisão do magistrado, nem mesmo produzir provas, não restando a ele prejuízo de ser citado a posteriori, ainda que por edital, permanecendo os ditames do devido processo legal. Entretanto, imagina-se como ficaria a irreversibilidade da decisão liminar caso o réu voltasse e descobrisse que casado não mais estava.

Afirma Cristiano Chaves de Farias e Nelson Rosenvald (2003, p. 104), que a questão da irreversibilidade, nesta decisão, é irrelevante, uma vez que há cognição 


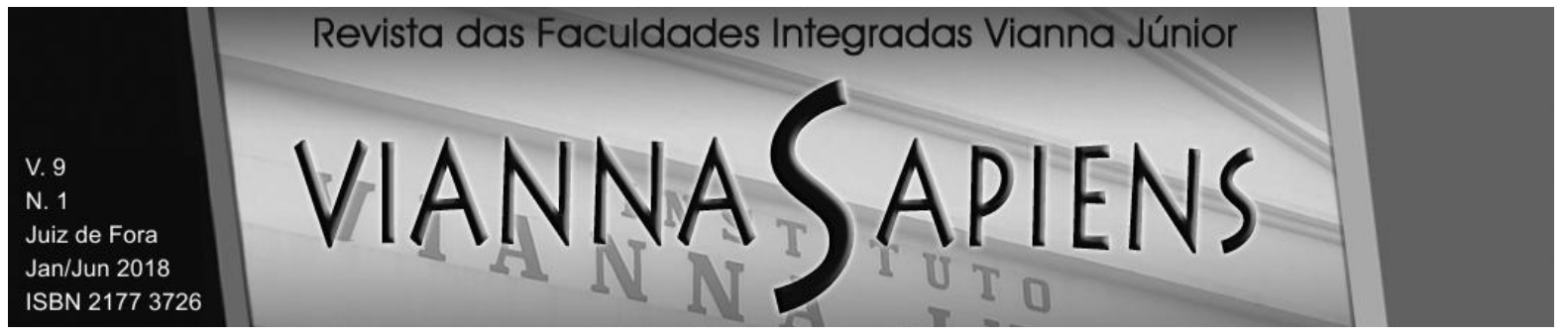

exauriente e juízo de certeza, e completa que tendo em vista que a tutela não se funda em um juízo de probabilidade, não há razão para se temer a irreversibilidade. O intuito principal de se requerer a decretação do divórcio foi livrar a autora das amarras de uma relação, há 42 anos fictícia, para se entregar por completo a uma nova fase e concretizar um novo relacionamento, já em construção, conforme o caso concreto analisado.

Alegado foi anteriormente que, assim como para casar deve haver o sim de ambos os cônjuges, para que haja a separação também deve haver a concordância. Seria perfeito se seguisse a ordem natural das coisas, mas o ser humano não é assim. Prova disso é que o réu permaneceu desaparecido por tanto tempo. Seria, ou não seria, uma manifestação de vontade tácita em separar?

\section{DO DIVÓRCIO INALDITA ALTERA PARTE}

Concedido pela primeira vez no país por um Juiz do Estado da Bahia, na Comarca de Salvador, a decisão liminar da decretação do divórcio foi inédita, no Brasil. Na época, o argumento utilizado para tal pedido - até então nunca feito - foi do afastamento da culpa na separação conjugal pós EC n 66 de 2010, além das questões afetivas e amorosas muito bem suscitadas.

O pedido, que deu start para um novo leque de possibilidades judiciais na atualidade brasileira, foi elogiado e consagrado por vários juristas, um deles Pablo Stolze (2014, apud GOMES, 2014) que afirmou que a medida foi louvável para evitar um desnecessário prolongamento da demanda, ao mesmo tempo em que se discutem assuntos desgastantes, como filhos e bens.

Alberto Raimundo Gomes dos Santos, juiz a tomar a decisão no processo de $\mathrm{n}^{\circ}$ 0518107-66.2013.8.05.0001, do Tribunal de Justiça do Estado da Bahia, entendeu que havia a necessidade da realização da vida afetiva dos cônjuges, uma vez declarada a incapacidade de reestruturação da sociedade conjugal. No corpo da 


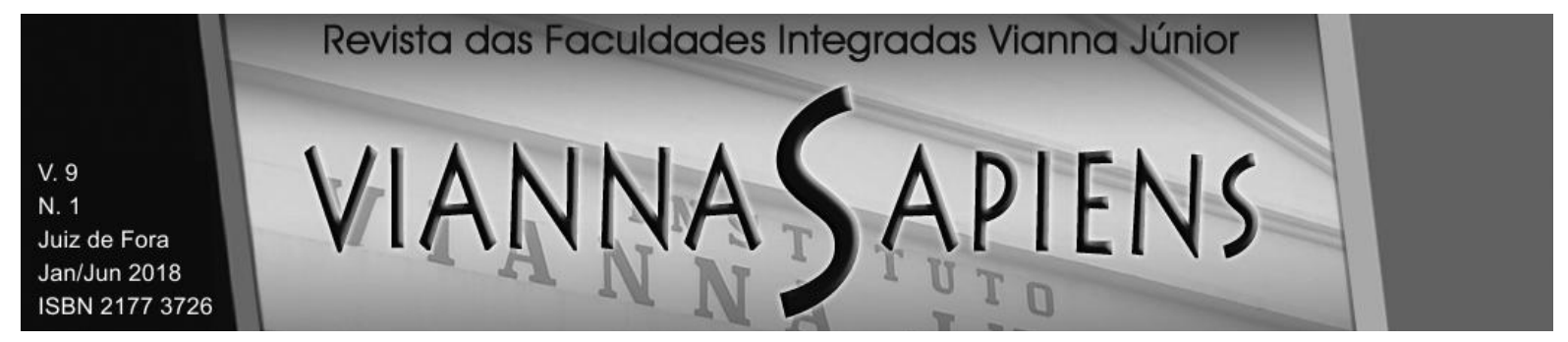

decisão, fundamentou o magistrado:

Manter-se casado é matéria apenas de direito e, quanto às demais questões, que porventura possa a ré pretender se indispor, poderão ser objeto de debate continuado nos próprios autos, liberando portanto as partes para a realização da felicidade afetiva. Santos (2014 apud SILVA, 2016).

Antes mesmo de se falar em divórcio liminar, havia algumas decisões no país que, ligeira e timidamente, já apresentavam nuances de privilegiar a felicidade afetiva. É a ementa do presente julgado no Tribunal de Justiça do Estado da Bahia, em 2007:

DIVÓRCIO LITIIOSO (DIRETO) - 1673249-3/2007. Autor(s): Sílvia Cátia Duarte Silva Fernandes. Advogados(s): Defensoria Pública do Estado da Bahia. Réu(s): Osvaldo Fernandes da Glória. Depoimentos testemunhais não deixam dúvidas quanto à procedência do suporte fático da pretensão, também demonstrando a impossibilidade de reconstituição da vida em comum, face ao longo lapso de separação de fato entre os cônjuges, pela ausência do réu. Demais disso, favorável decretar o divórcio pleiteado e a partilha dos bens acaso existentes. Arquivem-se os autos. (ass) Rosalino dos Santos Almeida. Juiz de Direito. (TJBA, Sentença n. 1673249-3/2007, da Capital. Juiz: Rosalino dos Santos Almeida. Data de Julgamento: 19/03/2009).

A decisão dos juízes coaduna com os princípios do direito de família da modernidade. Há de se entender as necessidades de cada casal e não aplicar a norma de forma genérica. É esse o papel do intérprete e aplicador do direito. Aliás, o casal deve ser livre para uma nova vida afetiva, não deixando de lado o respeito e a história construída.

\subsection{Da não concessão do divórcio inaudita altera parte}

Em análise a vários julgados ocorridos posteriormente ao caso narrado acima, válido é ressaltar aqueles em que o pedido não foi vitorioso, e consequentemente, 


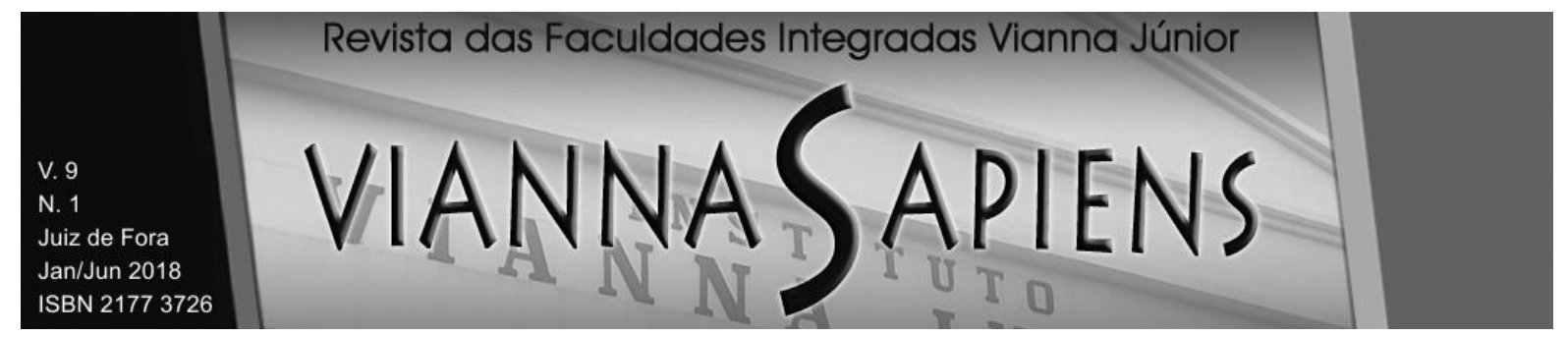

seus respectivos argumentos que levaram à improcedência do mesmo. O grande objetivo deste estudo não é chegar a uma análise e resultado final engessado sobre se caberia, ou não, tal requerimento. O grande objetivo é questionar as possibilidades a partir das brechas da lei.

$\mathrm{Na}$ ementa do acórdão abaixo, também julgado pelo Tribunal de Justiça do Estado de Minas Gerais, Agravo de Instrumento $n^{\circ}$ 10707140287384001, o indeferimento da medida e o não provimento do recurso foram dados com a alegação de que não havia motivos relevantes para fundamentar a urgência do pedido, e ainda, que claro seria a violação aos princípios da ampla defesa e do contraditório.

Observa-se:

Ementa: Agravo de Instrumento. Ação de divórcio litigioso. Antecipação de tutela. Requisitos ausentes. Decretação do divórcio inaudita altera pars. Violação dos princípios do contraditório e da ampla defesa. Indeferimento da medida. Necessidade. Recurso provido. Agravo de instrumento-cv № 1.0707.14.028738-4/001 Comarca de Varginha - agravante (s): Nelson Pereira de Andrade agravado (a)(s): Neusa Aparecida da Silva Andrade.a c ó r d ã o . Des. Caetano Levi Lopes relator. Des. Caetano Levi Lopes (relator). $\mathrm{V}$ o to desa. Hilda Teixeira da costa - de acordo com o (a) relator (a). Des. Marcelo Rodrigues - de acordo com o (a) relator(a). (tjmg, agravo de instrumento n. 10707140287384001 , da capital. Relator: des. Marcelo Rodrigues, data do julgamento: 21/07/2015).

Ainda que com base do Código de Processo Civil de 1973, nada impede de serem analisados os aspectos materiais e processuais de forma conceitual, independente da nova legislação em vigor. O recurso foi interposto contra uma decisão interlocutória que deferiu o divórcio a título liminar, entendendo que restavam presentes o periculum in mora e o fumus boni iuris. Entretanto, o principal argumento que impediu que o Agravo vigorasse foi a indicação de violação ao princípio do contraditório. Alega-se que para que a medida seja concedida, o Juiz deve estar convencido da probabilidade, porém não da certeza, do direito das partes e dos objetivos que pretendem ver com a antecipação dos efeitos da tutela 


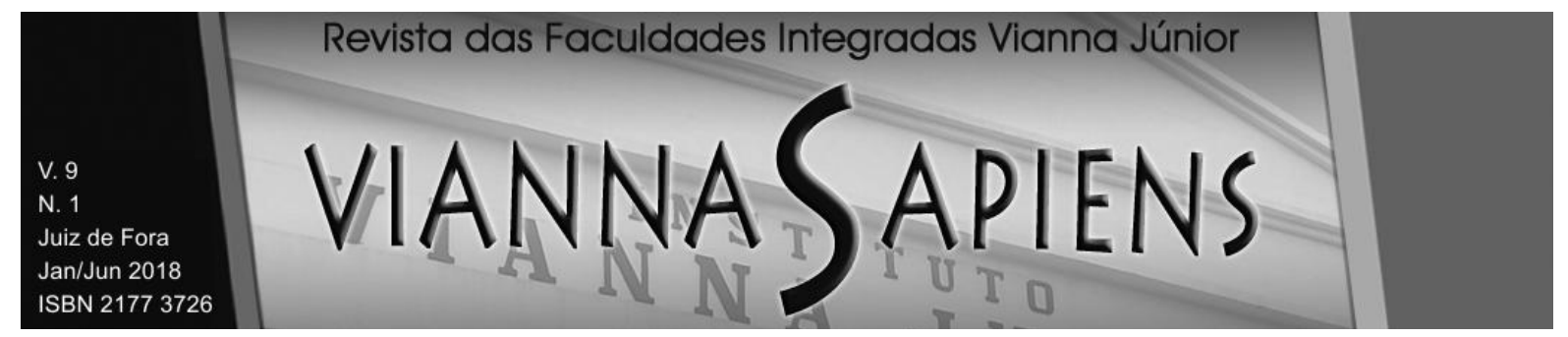

jurisdicional, não justificando, desta forma, a decretação - que foi determinada de 'prematura' - neste momento processual. Ao final das argumentações, afirma-se insustentável manter a decisão que possibilitou o divórcio liminar, por infringir o contraditório e a ampla defesa, revogando-se a decisão dada em primeiro grau na Comarca de Varginha, Estado de Minas Gerais.

O segundo caso é diferente do primeiro analisado no item 2.3 deste estudo. Aqui, comprova-se que o réu da ação de divórcio encontra-se em domicílio com a autora, ainda sob o mesmo teto, sendo totalmente possível sua citação para responder aos limites da lide do divórcio litigioso. No primeiro caso, o réu encontrava-se em local incerto e não sabido há mais de 42 anos, sendo inviável questioná-lo acerca do divórcio.

O ponto principal será sempre o contraditório. O abandono do lar independente das razões - por mais de quatro décadas acaba-se por consagrar uma separação tácita, que pelo próprio decurso do tempo, sem convívio matrimonial, leva ao fim da relação. Quanto ao abandono do lar, não se deve entrar no mérito. $O$ importante seria avaliar as possibilidades de cada caso concreto.

No primeiro, inviável encontrar o indivíduo depois de inúmeras tentativas frustradas de procuras incansáveis. Quanto mais se procura, mais tempo se leva. Seria correto procurar infinitamente por um réu que talvez não queira ser encontrado? E deixar uma esposa a mercê de um casamento puramente formalizado? Na mesma toada do julgado colacionado anteriormente, relatado pelo Desembargador Dr. Marcelo Rodrigues, do TJMG, é também o posicionamento do Tribunal de Justiça do Estado de Santa Catarina, pelo voto do Desembargador Dr. Marcus Túlio Sartorato, no Agravo de Instrumento n²014.013762-3, da capital:

Família. Ação de divórcio. Liminar requerida inaudita altera pars. Indeferimento pelo magistrado a quo. Verossimilhança delineada pela manifestação de vontade de término do casamento. Fundado receio de dano irreparável ou de difícil reparação. Ausência de comprovação de interesse em contrair novas núpcias ou de prejuízo na manutenção do estado civil atual até que seja oportunizada a defesa. Fato do réu encontrar-se em local incerto e não sabido que pode ser solucionado com a citação por edital. Pressupostos 


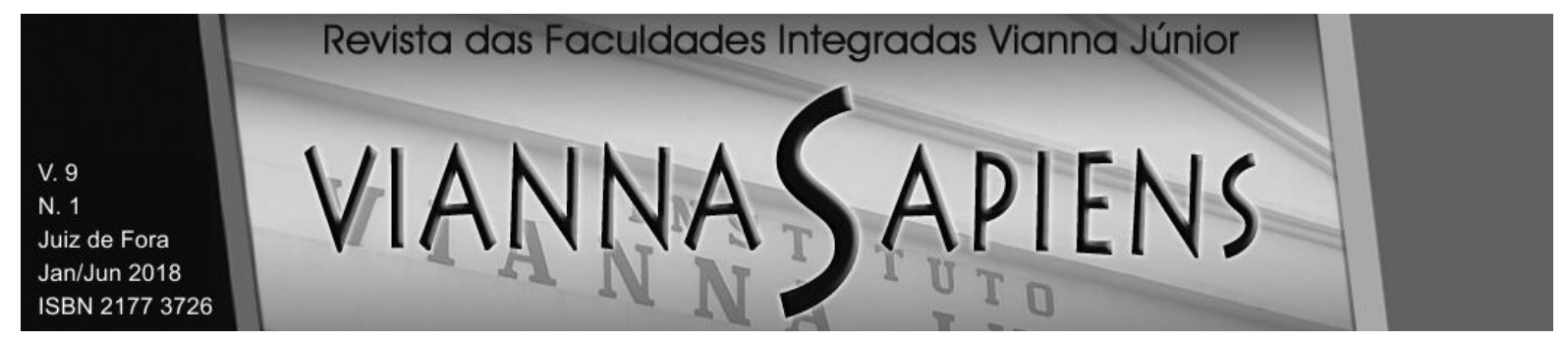

autorizadores da medida liminar não verificados. Interlocutório mantido. Recurso desprovido. Não só é prudente, como recomendável ao Magistrado, que nas ações de divórcio ouça a parte autora pessoalmente sobre o pedido para aferir se 0 faz espontaneamente.

(TJ-SC - AG: 20140137623 SC 2014.013762-3 (Acórdão), Relator: Marcus Tulio Sartorato, Data de Julgamento: 21/07/2014, Terceira Câmara de Direito Civil Julgado).

Assim, fato que não há respostas prontas para as diversas indagações feitas ao longo desde trabalho. O mais importante é não perder a sensibilidade de questioná-las e de buscar meios - como forma de respostas - para não fragmentar ainda mais as relações humanas.

\subsection{Dos limites da autonomia da vontade dos cônjuges litigantes}

Na mais singela conotação da palavra vontade, para Silveira Bueno (2001, p. 657), é a faculdade de querer; desejo; resolução; designo; espontaneidade. Já nos ensinamentos de Aurélio Buarque de Holanda Ferreira (2004), diz-se 'vontade':

Faculdade de representar mentalmente um ato que pode ou não ser praticado em obediência a um impulso ou a motivos ditados pela razão; sentimento que incita alguém a atingir o fim proposto por esta faculdade; aspiração; desejo; anseio.

Para a escritora Ana Alvarenga Moreira Magalhães (2010, p. 9), o vocábulo vontade, no mundo jurídico, deve ser entendido em dupla face, sendo a primeira a concepção do objeto do querer, a fim de perseguir o que é da vontade. Em outra, adquire a interpretação de faculdade, ou, como a própria autora menciona, atividade do querer como fato psíquico interno, de modo a exteriorizar ao mundo jurídico a concretude da vontade. E complementa:

A vontade que interessa ao Direito é aquela manifestada, exposta, ainda que não o seja de maneira livre, ou consciente, ou íntegra. A partir da manifestação é que se conhece o "querido", e somente a 


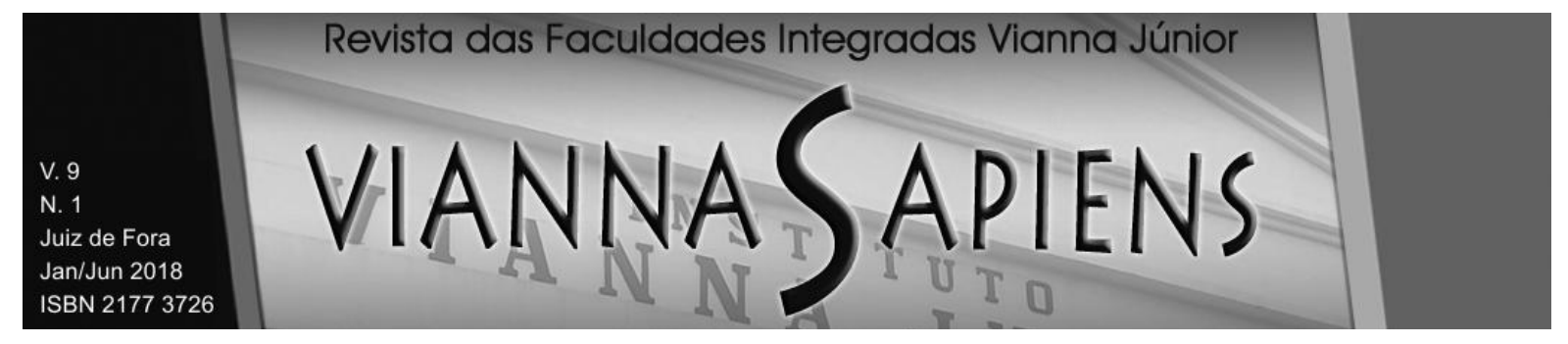

partir daí ela chama para si a responsabilidade de criação de deveres e obrigações a partir dos negócios jurídicos.

É a vontade íntegra que constitui o próprio negócio jurídico. Já falava Rosenvald e Farias (2014), sobre a manifestação da vontade como requisito único e imprescindível para a celebração do negócio jurídico casamento, e por consequência, o rompimento do vínculo. Não será analisado neste simplório estudo os vícios da vontade. Delimita-se o tema na questão dos limites da autonomia da vontade na repercussão do negócio jurídico celebrado, ressaltando as possibilidades dessa vontade não se formar, não se concretizar ou não se manifestar, de forma perfeita. Como exemplo ilustrativo, o caso do divórcio liminar ocorrido na cidade de Juiz de Fora. O réu, que em local incerto e não sabido, não detinha possibilidades de manifestar sua vontade, positiva ou negativa, pela separação. Ainda assim, a medida liminar foi deferida em grau recursal, suprimindo os limites da autonomia da vontade, neste caso.

A grande questão é a vontade como elemento existencial do divórcio. A autonomia da vontade, tratada como princípio no Ordenamento Jurídico Pátrio, dispõe que, todos os indivíduos que possuem capacidade jurídica plena podem praticar e assumir atos e obrigações, de acordo com o seu querer, ou seja, sua vontade. A origem do princípio consagrou-se nos ideais trazidos pela Revolução Francesa do século XVIII, quais sejam, "liberdade, igualdade e fraternidade". Nos ensinamentos de Savigny (apud AZEVEDO, 2002, p. 4), a autonomia da vontade é destinada a produzir efeitos. E proclama Savigny (apud FERRER CORREIA, 1939, p. 32):

A vontade deve ser pensada como a única coisa importante e eficaz; mas, como facto interior e invisível que é, ela carece de um sinal que a torne reconhecível por outros; e este sinal, por cujo intermédio a vontade se manifesta, representa-o precisamente a declaração.

A autonomia da vontade, muito utilizada no direito contratual, cabe perfeitamente ao tema se concordarmos em dizer que o casamento possui, como 


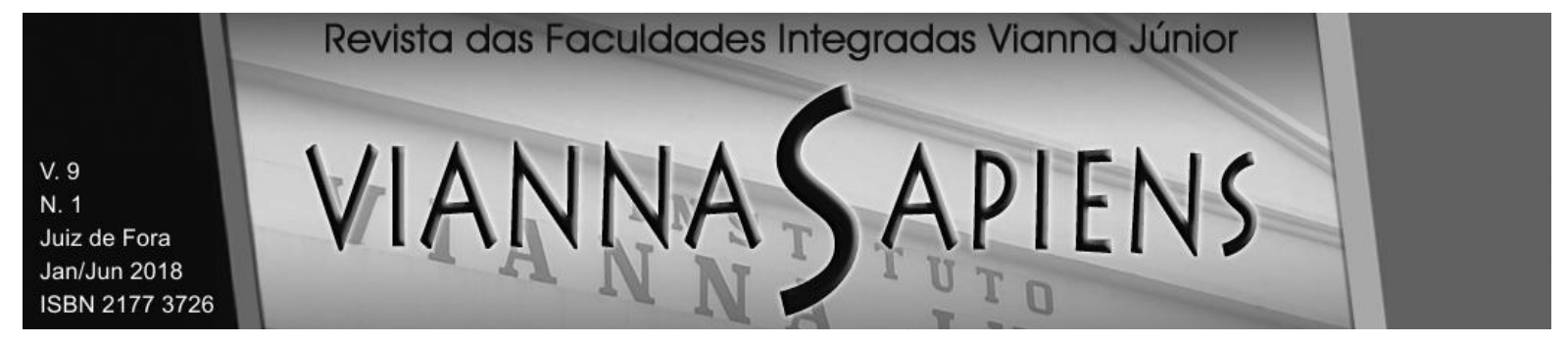

natureza jurídica, o contrato. Por Nelson Rosenvald e Cristiano Farias (2014, p. 401), o único requisito exigido para o divórcio, é, exatamente, o desafeto, ou seja, a manifestação da vontade dentro do negócio jurídico denominado casamento, da falta de vontade de permanecer casado, chamado, em latim, de voluntas divorciandi.

Há de se ressaltar que até mesmo o término da discussão da culpa no fim do relacionamento perpetuou, ainda mais, o que acredita implantar a autonomia da vontade, sob o viés de que cada qual é responsável e dono de suas condutas, não subsistindo somente a um dos cônjuges a responsabilidade pelo fim do relacionamento. Se um matrimônio é constituído por duas pessoas, nada mais coerente - e possível - de haver falhas e conflitos no relacionamento por ambos os lados.

Logo, pelo viés liberalista que tende a preceder as novas relações humanas, a vontade é, portanto, a possibilidade de defender a liberdade de quem lhe empresta o nome. Daí nasce a autonomia, sendo esta a aptidão para a vontade individual. A autonomia deve seguir o bom senso. Não basta ter vontade, deve ser livre para a vontade ser exercida. Deve-se ter autonomia de exercer a vontade (MAGALHÃES, 2010, p. 11).

Neste estudo, o questionamento é qual princípio prevalecerá quando da concessão do divórcio inaudita altera parte. A concessão do pleito no caso ocorrido em Juiz de Fora, Minas Gerais, colocou o princípio da autonomia da vontade em detrimento dos princípios processuais. Nota-se, portanto, que houve um conflito entre normas-princípios, ou seja, entre os princípios propriamente ditos. Quando se depara com conflitos normativos, neste caso, de normas-princípios, o critério utilizado para desfazer o conflito será a ponderação. Para que a ponderação seja aplicada, é necessário o uso dos postulados. Na teoria de Dworkin (1999, apud FERNANDES, 2013, p. 239) ponderar é nada mais do que refletir sobre alguma coisa.

Nas lições trazidas por Luís Roberto Barroso (2009, p. 334) a ponderação, em suma, consiste em uma técnica de decisão jurídica, aplicada a casos de difícil resolução, em relação aos quais a subsunção se mostrou insuficiente. E ainda 


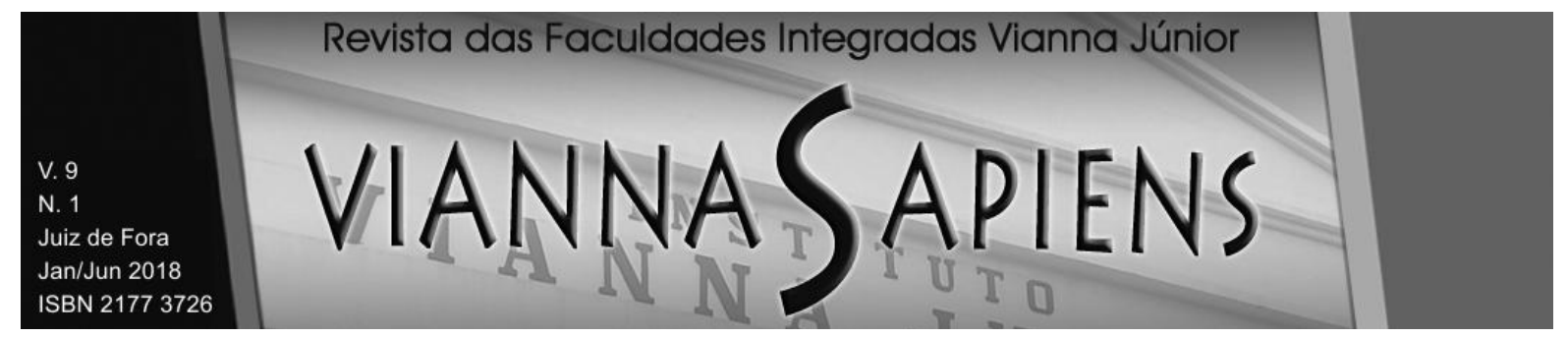

completa que "a insuficiência se deve ao fato de existirem normas de mesma hierarquia indicando soluções diferenciadas." Para Bernardo Gonçalves Fernandes (2013, p. 224):

Havendo uma colisão entre princípios, o valor decisório será dado a um princípio que tenha, naquele caso concreto, maior peso relativo, sem que isso signifique a invalidação do princípio compreendido como de peso menor.

Dependerá, portanto, do aplicador, ao analisar o caso concreto, valer-se da técnica constitucional da ponderação para resolver o conflito entre princípios, utilizando-se daquele que mais razoável será para o caso concreto.

Logo, conflitos envolvendo princípios seriam solucionados por meio de uma análise cuidadosa e pormenorizada da leitura que a sociedade (e não somente o intérprete) faz da sua história jurídica. Nessa leitura, devemos nos esforçar, ainda, para construir um esquema coerente de princípios e de regras que estão inscritos em nossa prática social (FERNANDES, 2013, p. 240).

Desta forma, a autonomia da vontade não pode ter forma pré-estabelecida e imutável, já que estamos falando de relações humanas fundadas em sentimentos. Da mesma maneira, no momento da separação, não devem existir amarras impostas. O casal se separa como achar melhor e mais conveniente: quando possível é o acordo, ou até mesmo, guiado pela discórdia, da maneira que consegue se separar, quando litigioso: resolve sobre os bens, os filhos, o patrimônio, a guarda, os assuntos domésticos, os animais de estimação. Os limites da autonomia da vontade não desaparecem, mas acredita-se que sejam delimitados pelas próprias partes, na medida em que conhecem seus próprios limites.

\subsection{Do divórcio como distrato}

Muito discutível é a natureza jurídica do casamento. Para os contratualistas, como por exemplo, Flávio Tartuce (2014, p. 21), a natureza jurídica do casamento 


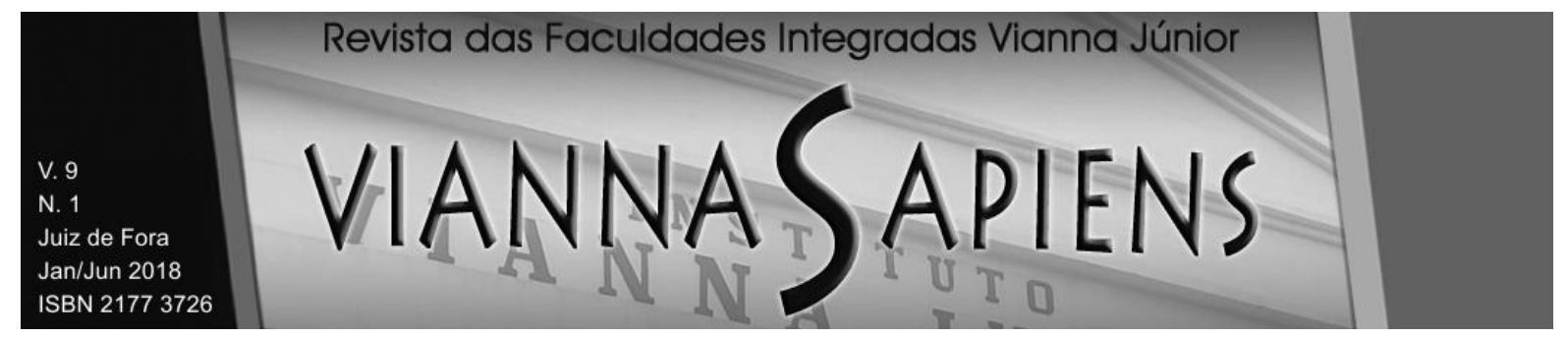

diz-se um contrato bilateral, sinalagmático e solene. Para Sílvio Rodrigues (2004, p. 21) o casamento é denominado um 'contrato de direito de família', a fim de diferenciá-lo dos demais contratos do mundo do direito privado por ter elementos únicos e particularidades inconfundíveis. Não há posicionamento certo ou errado, o divertido é entender os diversos caminhos. Nos ensinamento de Espínola (apud VENOSA, 2004, p. 21):

O casamento é um contrato que se constitui pelo consentimento livre dos esposos, os quais, por efeito de sua vontade, estabelecem uma sociedade conjugal que, além de determinar o estado civil das pessoas, dá origem às relações de famílias reguladas, nos pontos essenciais, por normas de ordem pública.

Pelo que apregoa Carlos Roberto Gonçalves (2011, p. 40) a visão contratualista - e individualista - do casamento, foi originada no Código Napoleônico do século XIX, considerando que a validade e eficácia do negócio dependeriam exclusivamente da vontade das partes. E corrobora ainda que "assim, o consentimento dos contraentes constituía elemento essencial de sua celebração e, sendo contrato, certamente poderia dissolver-se por um distrato. A sua dissolução ficaria, destarte, apenas na dependência do mútuo consentimento."

O casamento é um contrato sui generis. (GONÇALVES, 2011). Entretanto, para Nelson Rosenvald e Cristiano Farias (2014, p. 183), o casamento pode, sim, ser entendido como negócio jurídico, porém, negócio jurídico este que não pode ser confundido com contrato. O que se quer dizer é que o casamento não é contrato, e sim, está contrato, devido à liberdade conferida aos nubentes, inclusive no que concerne à sua dissolução pelo divórcio, que possui hoje características que o aproximam mais de negócio jurídico, do que de instituição. (ROSENVALD e FARIAS, 2014).

Ainda que alguns autores entendam o casamento como instituição, e não contrato, não se pode deixar de observar o substrato contratual que se recheia a união. Desta forma, conceituando a doutrina contratual o casamento como um contrato, ele necessariamente poderia ser dissolvido por distrato, ficando sua 


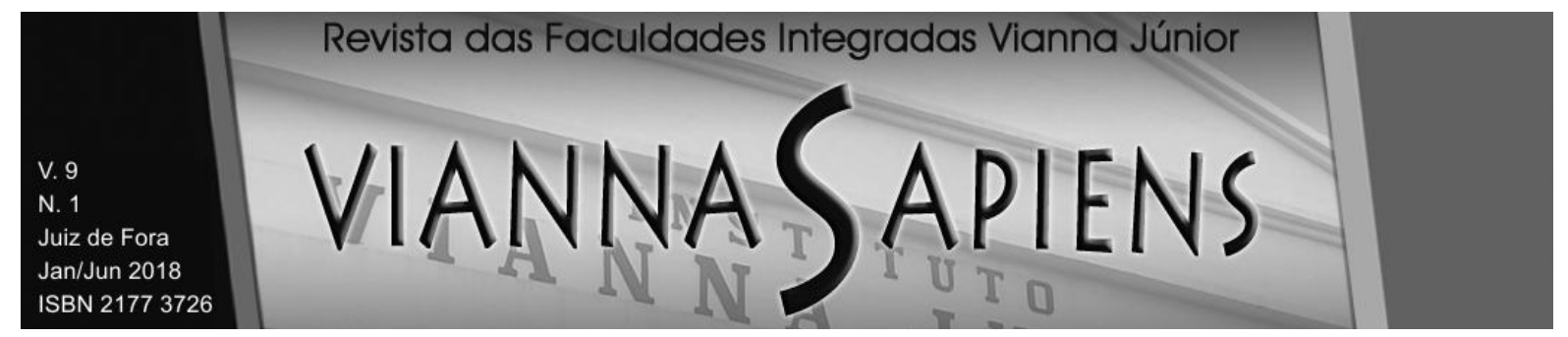

dissolução dependente do mútuo consentimento. O distrato, previsto no art. 472 do Código Civil de 2002, dispõe que este resultará da mesma forma exigida para o contrato. Em suma, distrato é uma das vertentes de resilição, modo de extinção dos contratos, juntamente com a quitação, resultando no término do negócio jurídico.

Na lição de Caio Mário da Silva Pereira (2004, p. 58), distrato é a declaração de vontade das partes contratantes, no sentido oposto ao que havia gerado o vínculo. E completa que, distrato, é o contrarius consensus dos romanos. Algumas vezes chamado de mútuo dissenso, todo contrato pode cessar pelo distrato. Para Flávio Tartuce (2014, p. 249) o distrato existe quando a lei previr a extinção do negócio como um direito potestativo reconhecido à própria parte ou às partes, podendo ser feito mediante um novo negócio jurídico ou não. Sendo esta dissolução bilateral - como, em regra, é - as formalidades do art. 166 do Código Civil de 2002 devem ser obedecidas: se o casamento foi celebrado por escritura pública, também deve ser o divórcio, ainda que extrajudicial, como visto anteriormente.

Perceptível mais uma vez fica a declaração de vontade das partes no momento do divórcio, uma vez que se conceitua o divórcio como distrato, a partir do casamento como contrato. Sendo um negócio jurídico formal e solene, não haveria, a princípio, a possibilidade de divórcio sem o mútuo consentimento. Sabe-se que as visões das leis, pelos aplicadores do direito, podem ser como caleidoscópios: a cada ângulo visto descobre-se uma faceta diferente.

Nesta toada, finaliza Roselvald e Farias (2014, p. 184) que com as novas possibilidades do divórcio extrajudicial trazidas pela alvorada do século XXI, extingui-se, em parte, as discussões infinitas acerca da natureza jurídica do casamento, já que, para seu término, é imprescindível - em ressalvas - o mútuo consentimento das partes, caracterizando, de plano, seu viés contratual:

Naturalmente, trata-se de um negócio jurídico especial, de índole familiar, não se submetendo, diretamente, a todas as regras do direito contratual, em face de sua estruturação existencial. Assim, por exemplo, não incidem no casamento as regras sobre o equilíbrio econômico financeiro do contrato (CC, arts. 317 e 478). 


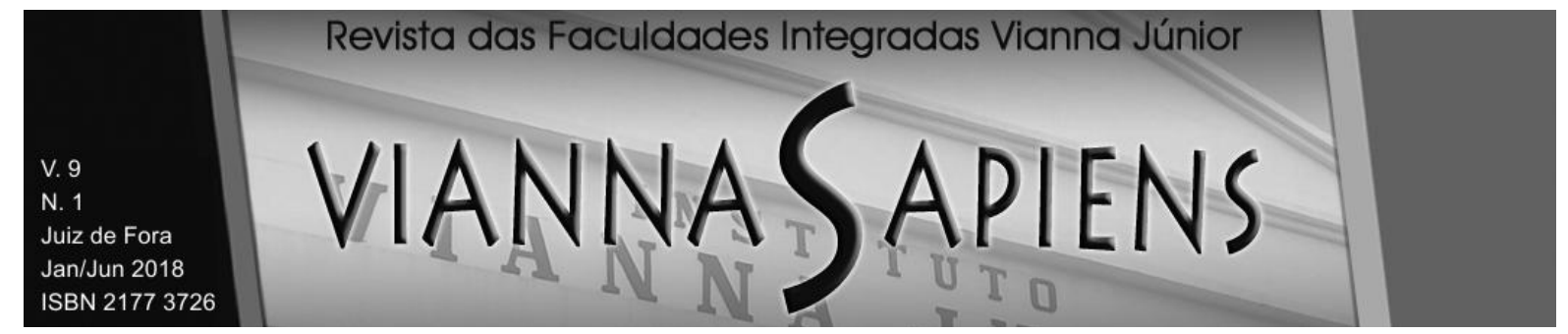

\subsection{Do direito de não permanecer casado e a busca pela antecipação da felicidade}

Felicidade afetiva. Foi um dos argumentos que levou o Juiz Dr. Alberto Raimundo Gomes dos Santos a proferir o primeiro divórcio liminar do Brasil. Parece distante a percepção de felicidade. Afinal, o que é? Felicidade é ventura, contentamento. Há quem diga que não há felicidade por completo. Isso dependerá da visão que cada pessoa tem sobre o que é ser feliz. Na linguagem dos gregos, eudaimon é o adjetivo para feliz, que significava 'um bem disposto que tem o poder para ser divino' (Angelita Cardua, 2008).

Os atuais estudos sobre a Psicologia da Felicidade têm demonstrado que parte da nossa condição de felizes é inata, uma predisposição genética que nos confere maior ou menor propensão para experienciar emoções positivas. Ou seja, um dom! A outra parte dessa condição diz respeito aos eventos de vida que influenciam nossa inserção no mundo. (CARDUA, 2008).

Para Aristóteles (384-322 a.C. apud CARDUA, 2008), a concepção de eudaimonia significava atingir um potencial pleno de realização de cada um, sendo a felicidade a meta da vida humana. Neste estudo, perceptível é a ideia de que ambos os cônjuges devem ser libertos para a realização da felicidade afetiva. Foi a frase utilizada pelo magistrado na prolação da decisão. Isso é possível de se perceber quando não há mais condições do relacionamento ser reerguido, e os cônjuges clamam por realizar novamente a vida afetiva.

O pedido liminar que há tanto se discute visa reparar essa lacuna. Para alguns, bobagem ou até mesmo frescura, seria tentar decidir com tanta agilidade a questão entre duas pessoas. Para isso, basta pensar em alguém que sente dor. Pergunte a ele quanto tempo dura um minuto: uma eternidade. Visto isso, para quem tem pressa de ser feliz, cada segundo é precioso, não se esquecendo dos princípios da proporcionalidade e razoabilidade que tanto regem o devido processo 


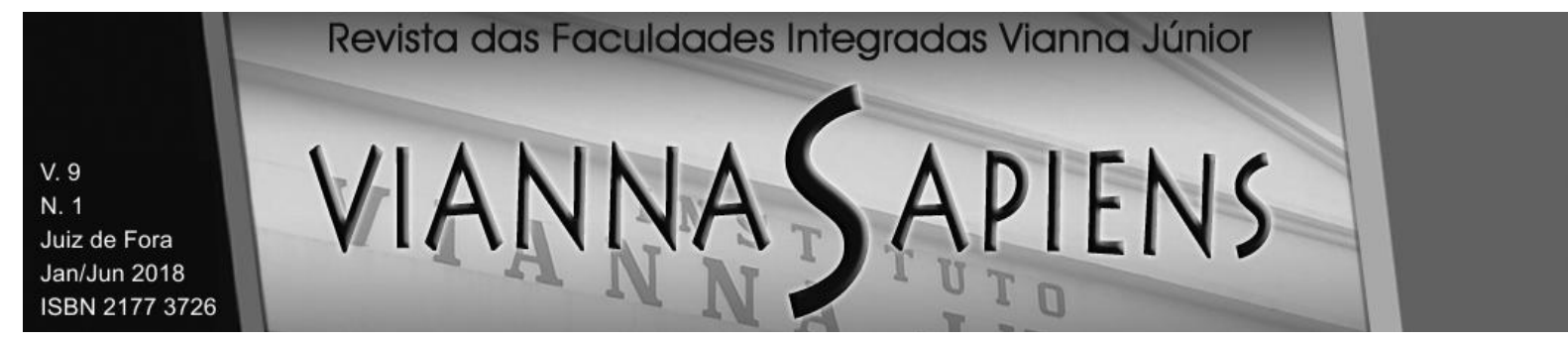

legal. ${ }^{3}$ Mister ressaltar que 0 grande ponto em questão foi o fim do afeto e a busca legal mais rápida para proporcionar felicidade às pessoas. Nos ditames de Pablo Stolze Gagliano e Rodolfo Pamplona Filho (2015, p. 12) acerca do caso:

Não há sentido em manter matrimonialmente unido um casal cujo afeto ruiu, enquanto se discutem os efeitos paralelos ou colaterais do casamento. Com a decisão do juiz da $6^{\mathbf{a}}$ Vara de Família, não havendo recurso pendente, qualquer das partes já pode se casar novamente, pois o divórcio é uma medida dissolutória do vínculo matrimonial válido.

E ainda completam que "certamente, são muitos os casos semelhantes, em todo o Estado, e é preciso que a Justiça busque esses caminhos legais para promover a felicidade das pessoas". (GAGLIANO e PAMPLONA FILHO, 2015).

O casal, após a separação, ficará desimpedido para nova vida afetiva, mas isso não descarta as responsabilidades e deveres com os filhos e demais obrigações, comprovando que é juridicamente possível o divórcio mediante medida liminar. No caso citado na cidade de Juiz de Fora, o pedido de divórcio liminar foi provido em sede de Agravo de Instrumento n¹.0145.11.029255-7/001, pelo voto da Desembargadora Relatora Dra. Albergaria Costa (apud MAZOCOLI, 2012) do Tribunal de Justiça do Estado de Minas Gerais, a saber:

A agravante é idosa, com 63 (sessenta e três) anos de idade, já se submeteu a tratamento de carcinoma por duas vezes e tem o desejo de casar-se com seu atual companheiro. Verifico, nesse caso específico, a alegada urgência necessária para o deferimento da pretensão inaudita altera parte, mormente considerando que já foi oficiada a Justiça Federal, Receita Federal e Cemig na tentativa, sem sucesso, de localizar 0 agravado. Ante o exposto, DOU PROVIMENTO ao recurso para deferir a antecipação de tutela e

\footnotetext{
${ }^{3}$ Nas lições de Luís Roberto Barroso (2013, p. 335), a razoabilidade e a proporcionalidade fazem parte de um fio condutor que passará por todo processo intelectual de aplicação quando da análise da ponderação de princípios. A razoabilidade e a proporcionalidade, que consubstanciam o devido processo legal material, são responsáveis pelo questionamento: "é razoável?", ou seja, qual princípio valerá em detrimento do outro, não havendo, neste caso, subsunção, nem hierarquia, especialidade ou generalidade entre os princípios. Neste estudo, a antecipação da felicidade foi guiada pelo princípio da autonomia da vontade em detrimento dos princípios processuais, aplicação que foi mais razoável ao caso concreto.
} 


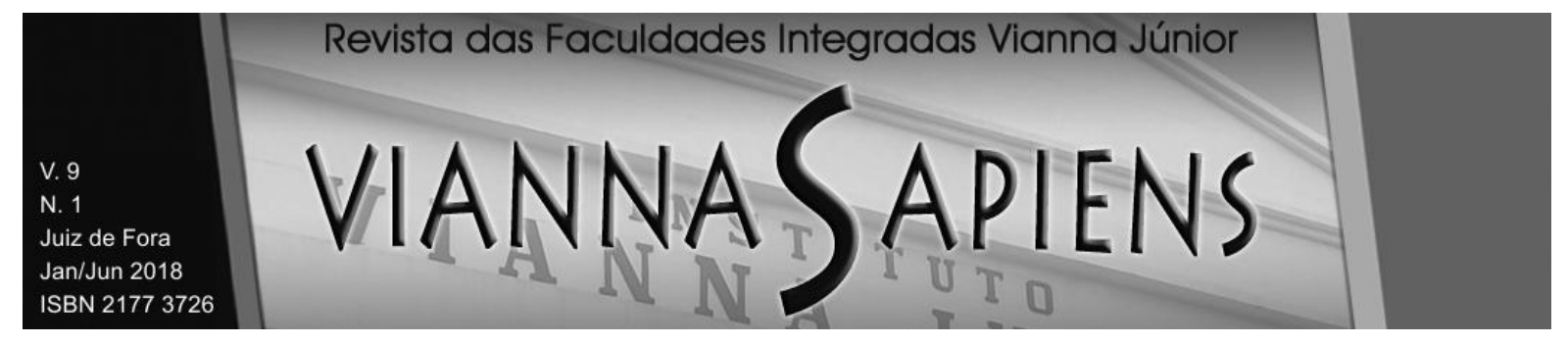

decretar o divórcio das partes.

Quando não há mais sentimentos e objetivos comuns, pura negação seria permanecer em uma união constringindo a liberdade de viver, e por via oblíqua, o direito à vida digna, muito garantido pelo princípio da dignidade da pessoa humana (art. $1^{\circ}, \mathrm{III}, \mathrm{CF} / 88$ ). É o que explica Nelson Rosenvald e Cristiano Farias (2014, p. 402) em sua obra de Direito de Família.

Primeiro, buscou-se a possibilidade de se extinguir o casamento. Logo, não bastava extingui-lo, como também tinha que ser feito de forma rápida, exaurindo os prazos. Tempos depois, não mais precisava o procedimento ser judicial, basta leválo ao cartório. Percebe-se que o direito evolui na medida em que a sociedade desenvolve-se tecnicamente. A sociedade, nos tempos em que vivemos, clama por paz, sossego e felicidade. Ingênuo é quem acredita que a felicidade é plena. O que existe são momentos felizes. É nesta busca incansável pela felicidade rápida e que preenche a vida das pessoas que os pedidos, na busca ao judiciário, são cada vez mais inéditos, reabrindo os conceitos de família, de casamento, de divórcio, e deixando para traz os tradicionais dilemas. Os dilemas agora são outros. São dilemas da família moderna.

Enquanto as separações judiciais mantiveram-se estáveis em relação a 2005 , com taxa de $0,9 \%$, os divórcios cresceram $1,4 \%$. Esse resultado revela uma gradual mudança de comportamento na sociedade brasileira, que passou a aceitar o divórcio com maior naturalidade, além na agilidade da exigência legal.

Esta é a análise de Gagliano e Pamplona Filho (2016, p. 48 e 49), segundo dados fornecidos pelo IBGE. Acolhedoras são as palavras de Maria Berenice Dias (2016, p. 212) quando nos referimos aos crescentes números de divórcio no país.

Certamente, ninguém acredita que uma pessoa vai casar simplesmente porque ficou mais fácil separar. Ora, quem está feliz não irá se divorciar somente porque agora o procedimento é mais rápido. Ao contrário, vai acontecer o aumento do número de casamentos, o que era obstaculizado pelos entraves legais à 


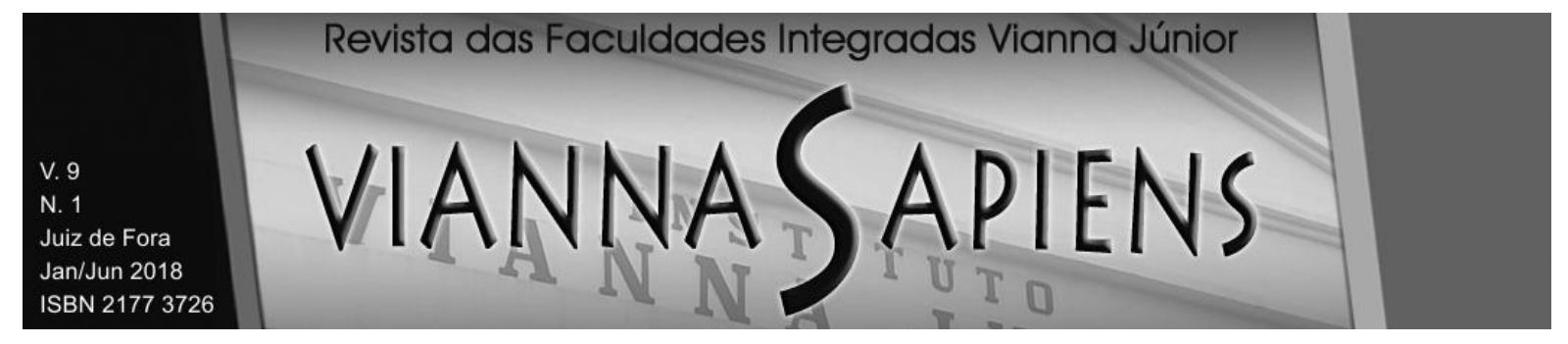

dissolução dos vínculos anteriores.

Nesta toada, os questionamentos que surgem no dia-a-dia, acabam por bater à porta do judiciário que, inerte, quando chamado, não poderá se abster de resolver o que lhe é apresentado - art. $3^{\circ}$ do Código de Processo Civil, que apregoa 0 princípio da inafastabilidade da jurisdição. Deste modo, questões simples chegam até os tribunais superiores, que, exercendo suas competências constitucionalmente previstas, decidem sobre temas de todos os tipos, até mesmo sobre a felicidade. Nota-se o posicionamento do Supremo Tribunal Federal acerca do tema:

O direito à busca da felicidade, implícito ao art. 11, III, da Constituição, ao tempo que eleva o indivíduo à centralidade do ordenamento jurídico-político, reconhece as suas capacidades de autodeterminação, autossuficiência e liberdade de escolha dos próprios objetivos, proibindo que o governo se imiscua nos meios eleitos pelos cidadãos para a persecução das vontades particulares. Precedentes da Suprema Corte dos Estados Unidos da América e deste Egrégio Supremo Tribunal Federal: RE 477.554-AgR, Rel. Min. Celso de Mello, DJe de 26/08/2011; ADPF 132, Rel. Min. Ayres Britto, DJe de 14/10/2011.

(RE 898060/SC, Relator(a): Min. LUIZ FUX, Tribunal Pleno, julgado em 21/09/2016, PROCESSO ELETRÔNICO DJe-187 DIVULG 23-082017 PUBLIC 24-08-2017)

E do relato deste julgado, proferido pelo Relator Ministro Luiz Fux, se extrai ainda a complementação de que:

O indivíduo jamais pode ser reduzido a mero instrumento de consecução das vontades dos governantes, por isso que o direito à busca da felicidade protege o ser humano em face de tentativas do Estado de enquadrar a sua realidade familiar em modelos préconcebidos pela lei.

Em outra decisão do STF, o Ministro Celso de Mello, em 2011, antes mesmo do nascedouro das discussões e análises sobre a felicidade afetiva consolidada no âmbito jurídico, já defendia o afeto como 'valor jurídico impregnado de natureza constitucional'. Observa-se: 


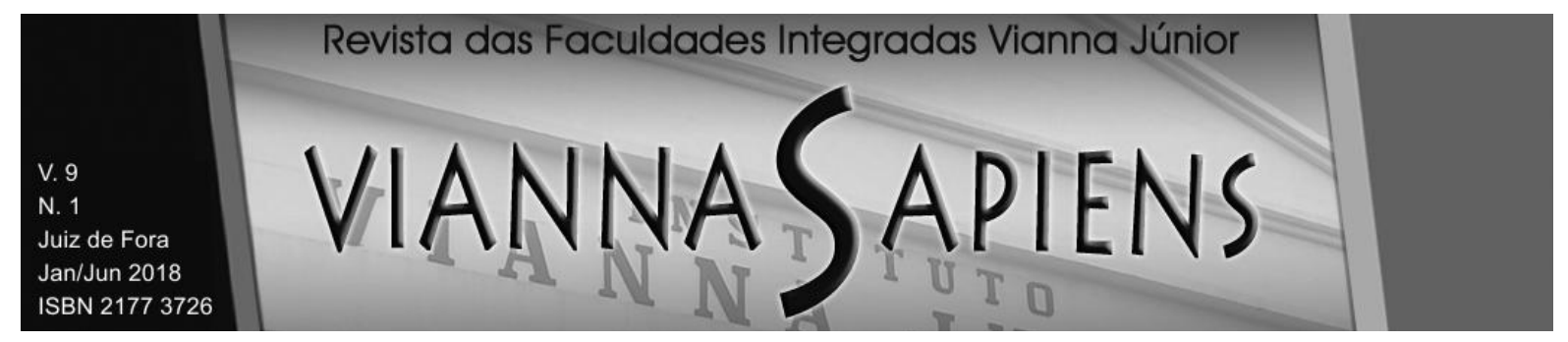

O afeto como valor jurídico impregnado de natureza constitucional: a valorização desse novo paradigma como núcleo conformador do conceito de família - o direito à busca da felicidade, verdadeiro postulado constitucional implícito e expressão de uma ideia-força que deriva do princípio da essencial dignidade da pessoa humana.

(RE 477554 AgR, Relator(a): Min. CELSO DE MELLO, Segunda Turma, julgado em 16/08/2011, DJe-164 DIVULG 25-08-2011 PUBLIC 26-08-2011 EMENT VOL-02574-02 PP-00287 RTJ VOL00220-01 PP-00572).

Este julgamento, que possui como percussor o debate dos direitos das minorias difundido por um Recurso Extraordinário do Estado de Minas Gerais, tocou - ou melhor - provocou a análise do STF para que afirmasse e declarasse, de forma aberta, que a questão da felicidade é sim, para ser discutida e porque não, a nível constitucional, uma vez que intrínseca é da natureza humana, não podendo, de forma alguma, ser desviada do debate jurídico.

O princípio constitucional da busca da felicidade, que decorre, por implicitude, do núcleo de que se irradia o postulado da dignidade da pessoa humana, assume papel de extremo relevo no processo de afirmação, gozo e expansão dos direitos fundamentais, qualificandose, em função de sua própria teleologia, como fator de neutralização de práticas ou de omissões lesivas cuja ocorrência possa comprometer, afetar ou, até mesmo, esterilizar direitos e franquias individuais. Assiste, por isso mesmo, a todos, sem qualquer exclusão, o direito à busca da felicidade, verdadeiro postulado constitucional implícito. (CELSO DE MELLO, 2011).

Tomando o viés de felicidade, conclui-se que ninguém se casa pensando em divorciar. O divórcio é consequência de uma vida conjugal insustentável, por diversos motivos. Importante é saber que as possibilidades legais devem ser servas da sociedade, a fim de proporcionar o que tanto se busca: harmonia e paz, já que ninguém pode viver ou manter uma família, em um ambiente conflituoso. $O$ importante é nunca desanimar de ser feliz. 


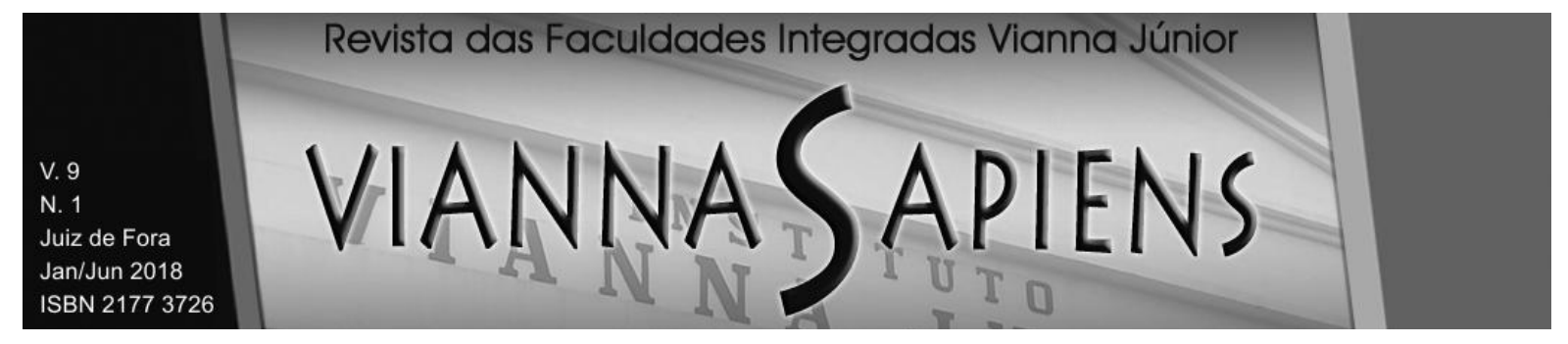

\section{CONSIDERAÇÕES FINAIS}

Viu-se no desenrolar deste artigo que há um dilema muito grande a respeito da violação dos princípios da ampla defesa e do contraditório quando da concessão do divórcio em caráter liminar, inaudita altera parte. Isso, porque se prima pela antecipação da felicidade das partes que não desejam mais permanecer casadas, obervando até que ponto sua autonomia da vontade será um empecilho.

$\mathrm{E}$, em conformidade com o que foi exposto, conclui-se que muito há para se discutir sobre a viabilidade do pedido, havendo divergências doutrinárias e jurisprudenciais sobre o tema. A grande questão é o porquê do pedido, sendo que seu fundamento seria a análise do caso concreto, juntamente com a interpretação da lei pelo jurista, a fim de promover a antecipação da felicidade desejada por quem não mais quer permanecer casado, levando em consideração as circunstâncias e a autonomia da vontade das partes litigantes.

A vista disso, percebe-se a preocupação com a violação dos princípios processuais da ampla defesa e do contraditório quando da cessão do divórcio em caráter liminar. Mostrou-se os posicionamentos dos tribunais superiores, em sede de recursos, sobre o tema, ficando claro que os princípios não precisam ser violados para que se conceda a justiça pleiteada, ainda que de forma inovadora. Logo, se deduz que a possibilidade da decretação do divórcio liminar inaudita altera parte ainda gerará inúmeras discussões e debates, uma vez que não há, ainda, posicionamentos consolidados sobre as discussões que ele provoca: o contraditório postergado, os limites da autonomia da vontade em detrimento dos princípios processuais e da busca pela felicidade como viés da dignidade da pessoa humana.

Assim sendo, mostra-se cabível o pedido de decretação do divórcio em caráter liminar inaudita altera parte, ficando a cargo do magistrado a análise do caso concreto e interpretação da norma pertinente a ser aplicada, de modo a facilitar a busca pela antecipação da felicidade dos cônjuges adversos, respeitando os princípios morais, éticos e, sobretudo, processuais. 


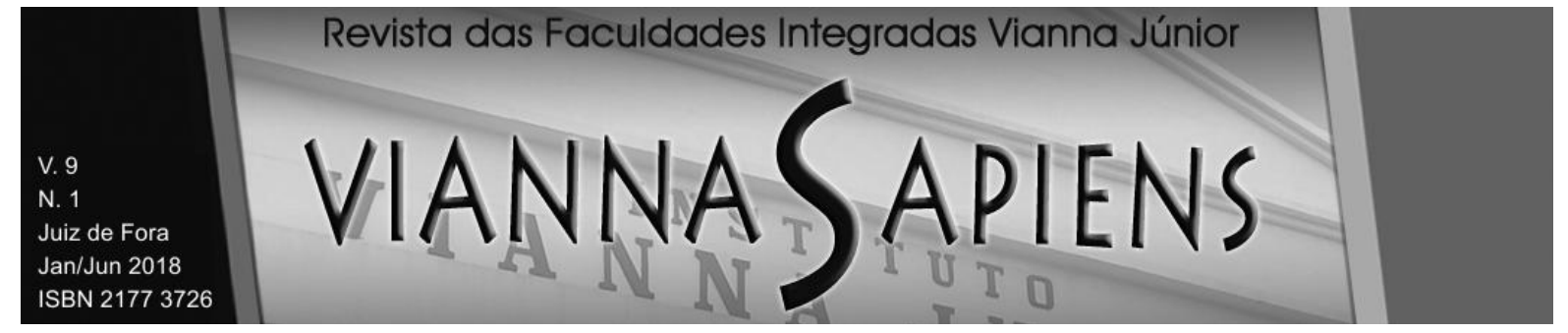

THE POSSIBILITY OF THE INALDITA ALTERA PARTE DIVORCE REQUEST:

The Precedural Principles versus the Autonomy of the Will

\begin{abstract}
This study aims to demonstrate the possibility of granting divorce in an unrestricted preliminary injunction, both in relation to a doctrinal and dogmatic analysis, as well as in the analysis of the cases cited, especially the first ones occurred in Brazil and in the city of Juiz de Fora, Minas Gerais. Thus, it is intended at the outset to show that despite the new judicial possibility resulting from the various needs of society and the marital life that is about to end, it will be necessary to observe the limits on which the request and the procedural principles of the ample defense and the adversary, due to due process of law, which should not be violated. Although, the nature of this research was based on the descriptive-interpretative method, using judgments, jurisprudence, doctrines, documents and analysis of judicial processes in order to obtain the qualitative result of this paper. In this way, it will be up to the judges and interpreters of the law, in the analysis of the specific case, to understand the circumstances that cause the request and the order of the same, in order to facilitate the divorce procedure by the willingness of the parties to advance the happiness that is so sought after the judicial request.
\end{abstract}

KEY-WORDS: DIVORCE. TEMPORARY RELIEF. INAUDITA ALTERA PARTE. HAPPINESS. AUTONOMY OF THE WILL. 


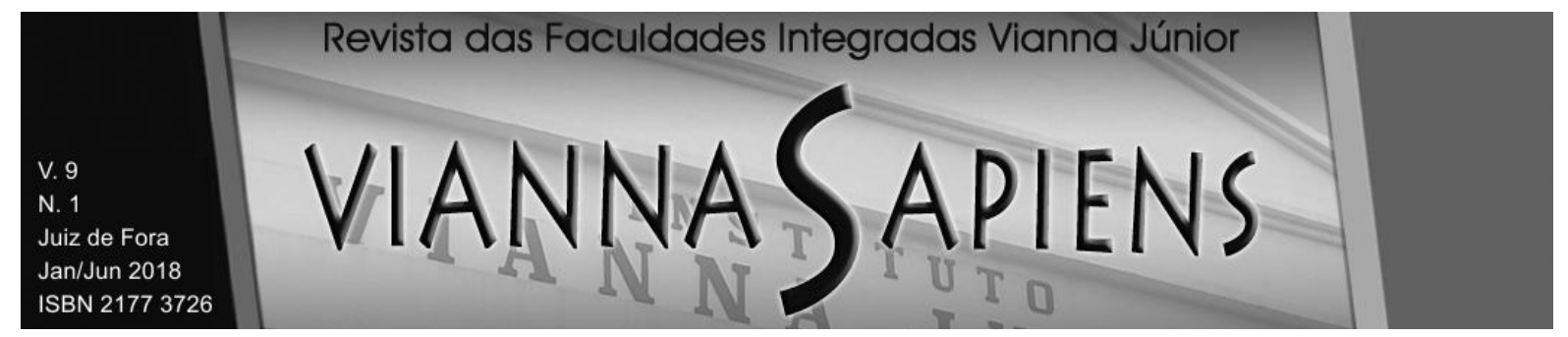

\section{REFERÊNCIAS}

ACQUAVIVA, Marcus Cláudio. Dicionário Jurídico. 6. ed. São Paulo: Rideel, 2013.

ALMEIDA, Rosalino dos Santos. Ementa: Divórcio Litigioso. Direto. Tribunal de Justiça da Bahia, 2017. Disponível em:

<http://www.tj.ba.gov.br/dpjonline/files/Comarca_16/Ed_711/CADERNO_UNICO/SE CAO_282/SUBSECAO_283/120130.html>. Acesso em 03 de setembro de 2017

AZEVEDO, Antônio Junqueira de. Negócio Jurídico: existência, validade e eficácia. 4. ed. São Paulo: Saraiva, 2002.

BARROSO, Luís Roberto. Curso de Direito Constitucional Contemporâneo: Os conceitos fundamentais e a construção do novo modelo. São Paulo: Saraiva, 2009.

BUENO, Cássio Scarpinella. Manual de Direito Processual Civil. 2. ed. São Paulo: Saraiva, 2016.

BUENO, Francisco da Silveira. Mini Dicionário da Língua Portuguesa. 10. ed. São Paulo, FTD, 2000.

BRASIL. Código Civil. In: VadeMecum Saraiva. 20. ed. São Paulo: Saraiva, 2015.

BRASIL. Código de Processo Civil. In:VadeMecum Saraiva. 20. ed. São Paulo: Saraiva, 2015.

BRASIL, Constituição Federal. In: VadeMecum Saraiva. 20. ed. São Paulo: Saraiva, 2015.

BRASIL, Supremo Tribunal Federal. Acórdão no Recurso Extraordinário n 898060/SC. Relator: FUX, Luiz. Publicado no DJ de 24-08-2017. Disponível em: <http://www.stf.jus.br/portal/jurisprudencia/listarJurisprudencia.asp?s1=\%28\%2AFEL ICIDADE\%2A\%29\&base=baseAcordaos\&url=http://tinyurl.com/ybk662cm>. 


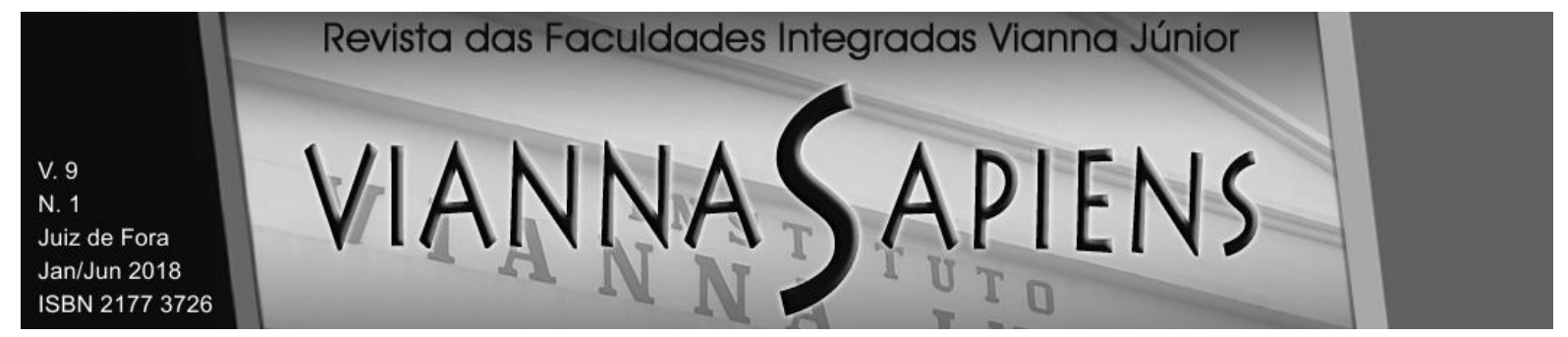

BRASIL, Supremo Tribunal Federal. Acórdão no Recurso Extraordinário n 477554/MG. Relator: MELLO, Celso. Publicado no DJ de 26-08-2011. Disponível em:

<http://www.stf.jus.br/portal/jurisprudencia/listarJurisprudencia.asp?s1=\%28\%2AFEL ICIDADE\%2A\%29\&pagina=2\&base=baseAcordaos\&url=http://tinyurl.com/ybk662cm $>$.

CARDUA, Angelita. Eudaimonia. Outubro, 2008. Disponível em:

$<$ https://angelitascardua.wordpress.com/2008/10/30/eudaimonia/>. Acesso em 30 de setembro de 2017.

DIAS, Maria Berenice. Manual de Direito das Famílias. 11. ed. São Paulo: Revista dos Tribunais, 2016

FARIAS, Cristiano Chaves de; ROSENVALD, Nelson. Curso de Direito Civil: famílias, v.6, 6. ed. Salvador: JusPodivm, 2014.

FERNANDES, Bernardo Gonçalves. Curso de Direito Constitucional. 5. ed. Salvador: JusPodivm, 2013.

FERREIRA, Aurélio Buarque de Holanda. Novo Dicionário Aurélio da Língua Portuguesa. 3. ed. Curitiba: Positivo, 2004

FERRER CORREIA, António de Arruda. Erro e interpretação da teoria do negócio jurídico. 4. ed. Coimbra: Almedina, 2001.

GAGLIANO, Pablo Stolze; FILHO, Rodolfo Pamplona. O novo divórcio. 3. ed. São Paulo: Saraiva, 2015.

GOMES, Nelci. Juiz concede primeiro divórcio por liminar na bahia. Salvador, TJBA, 2014. Disponível em: <http://tj-ba.justiça.inf.br/noticia/2014/07/juiz-concedeprimeiro-divórcio-liminar-bahia>. Acesso em 03 de setembro de 2017.

GONÇALVES, Carlos Roberto. Direito civil brasileiro: contratos e atos unilaterais, v.3, 8. ed. São Paulo: Saraiva, 2011. 


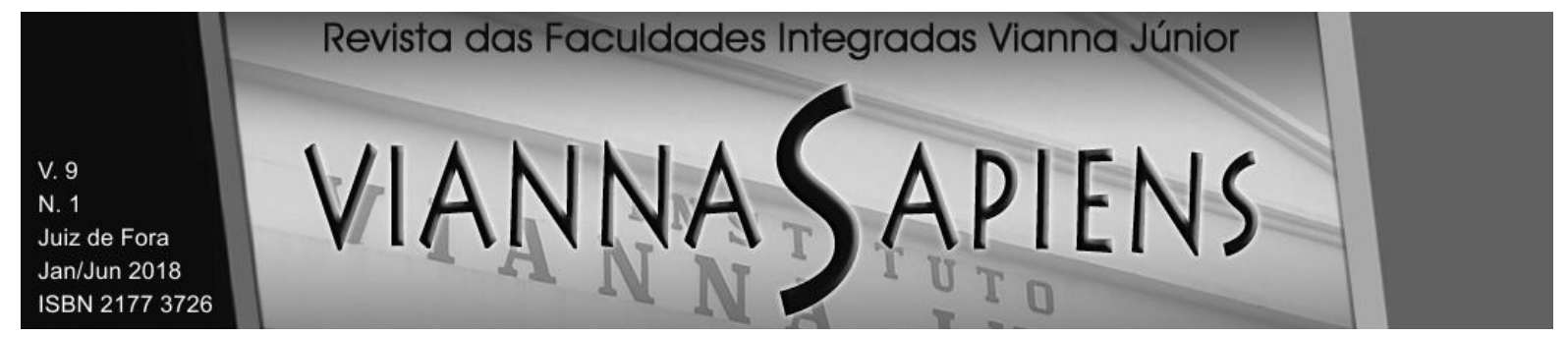

MAGALHÃES. Ana Alvarenga Moreira. O Erro no negócio jurídico: autonomia da vontade, boa-fé objetiva e teoria da confiança. 12. Ed. São Paulo: Atlas, 2011.

MAZOCOLI, Marcelo Santos. Pedido de antecipação de tutela recursal em agravo de instrumento $n^{\circ} 1.0145 .11 .029255-7 / 001$.Tribunal de Justiça de Minas Gerais, 2012.

NERY JÚNIOR, Nelson; ANDRADE NERY, Rosa Maria de. Código de processo civil comentado e legislação extravagante. 7. ed. São Paulo: RT, 2003.

PEREIRA, Caio Mário da Silva. Instituições de Direito Civil: direito de família, v.5, 14. ed. Rio de Janeiro: Forense, 2004.

RODRIGUES, Marcelo. Ementa: Agravo de Instrumento. Ação de divórcio litigioso...Tribunal de Justiça de Minas Gerais, 2017. Disponível em: <http://tjmg.jusbrasil.com.br/jurisprudencia/213216234/agravo-de-instrumento-cv-ai10707140287384001-mg/inteiro-teor-213216354>. Acesso em 03 de setembro de 2017

RODRIGUES, Sílvio. Direito civil: direito de família. 2. ed. São Paulo: Saraiva, 2004.

SARTORATO. Marcus Túlio. Ementa: Família. Ação de divórcio...Tribunal de Justiça de Santa Catarina, 2017. Disponível em: <https://tjsc.jusbrasil.com.br/jurisprudencia/25215845/agravo-de-instrumento-ag20140137623-sc-2014013762-3-acordao-tjsc/inteiro-teor-25215846?ref=juris-tabs>. Disponível em: 08 de julho, 2017.

SILVA, Clarice Claudino. Ementa: Ação de Divórcio...Tribunal de Justiça do Mato Grosso, 2017. Disponível em: <http://www.buscaoficial.com/c/diario/cx0yeieKt/>. Acesso: 08 de agosto, 2017.

SILVA, Tiago. Juiz da Bahia concede divórcio por liminar antes de ouvir uma das partes. Salvador: Assim Passei, 2017. Disponível em: $<$ http://www.assimpassei.com.br/inaudita-altera-pars-em-divorcio-juiz-da-bahiaconcede-divorcio-por-liminar-antes-de-ouvir-uma-das-partes/>. Acesso em 03 de setembro de 2017. 


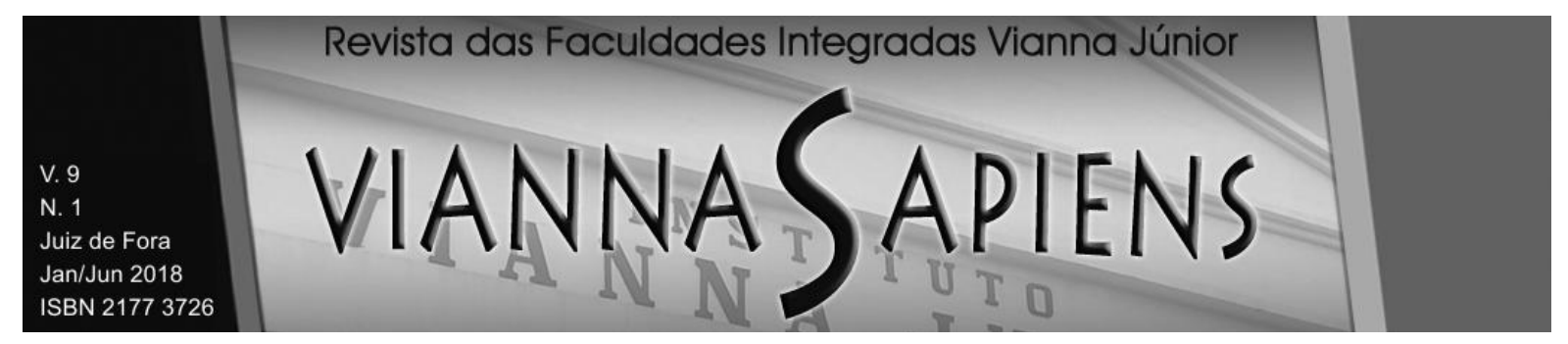

TARTUCE, Flávio. Direito Civil: teoria geral dos contratos e contratos em espécie, v.3, 9. ed. São Paulo: Método, 2014.

VENOSA, Silvio de Salvo. Direito Civil: direito de família. 3. ed. São Paulo: Atlas, 2003.

Recebido em 30/04/2018

Publicado em 13/08/2018 